\begin{tabular}{|l|l|}
\hline $\begin{array}{l}\text { 2. To: (Receiving Organization) } \\
\text { Distribution }\end{array}$ & $\begin{array}{l}\text { 3. From: Coriginating Organization) } \\
\text { Maintenance and Surveillance } \\
\text { Engineering }\end{array}$ \\
\hline 5. Proj./Prog./Dept./Div.: & $\begin{array}{l}\text { 6. Design Authority/ Design Agent/Cog. } \\
\text { W-320 }\end{array}$ \\
\hline
\end{tabular}

8. Originator Remarks:

For Approval and Release

11. Receiver Remarks: 11A:- Design Baseline Document? QJ Yes [] No

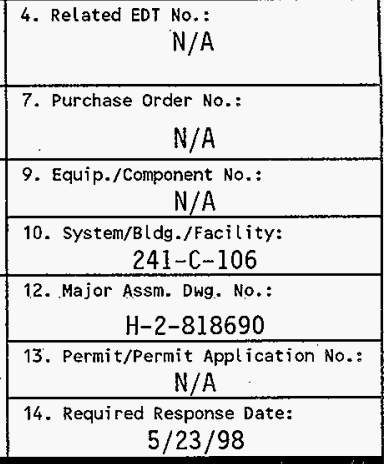

$5 / 23 / 98$

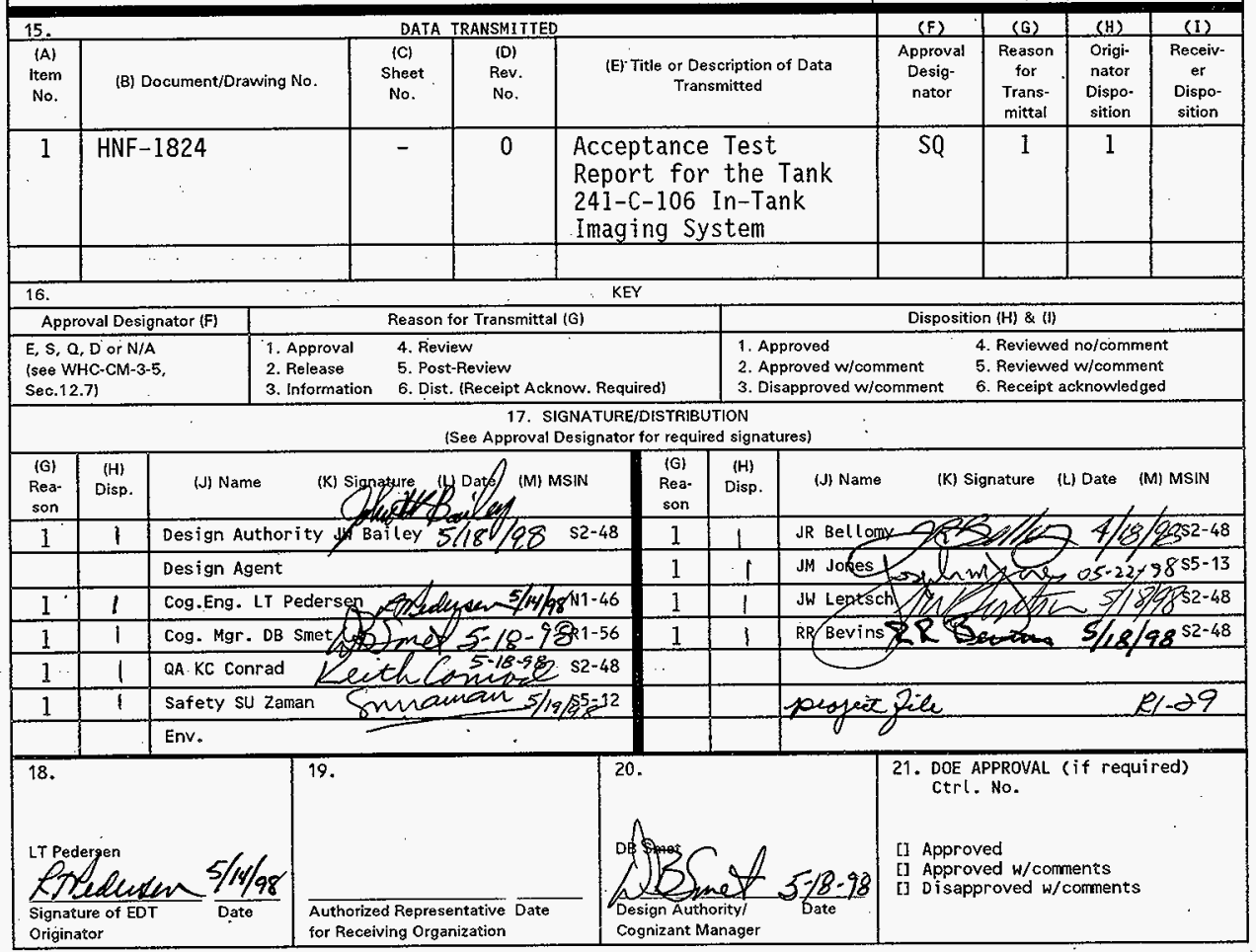

BD-7400-172-2(05/96) GEF097 


\section{Acceptance Test Report for the Tank 241-C-106 In-Tank Imaging System}

\section{LT Pedersen}

Lockheed Martin Hanford Company, Richland, WA 99352

U.S. Department of Energy Contract DE-AC06-96RL13200
EDT: 617463
Org Code: 74720
UC: 506
B\&R Code: EW3130010
Charge Code: D2MNN
Total Pages: 69

Key Words: Project $W-320$, CCTV, camera, sluicing

Abstract: This document comprises the acceptance test report for the Project $W-320$ In-tank Imaging (CCTV) System. This document contains completed copies of the acceptance test procedures as attachments.

TRADEMARK DISCLAIMER. Reference herein to any specific comercial product, process, or service by trade name, trademark, manufacturer, or otherwise, does not necessarily constitute or imply its endorsement, recommendation, or favoring by the United States Government or any agency thereof. or its contractors or subcontractors.

Printed in the United States of America. To obtain copies of this document, contact: Document Control Services, P.O. Box 950, Mailstop H6-08, Richland WA 99352, Phone (509) 372-2420;

Fax (509) 376-4989.
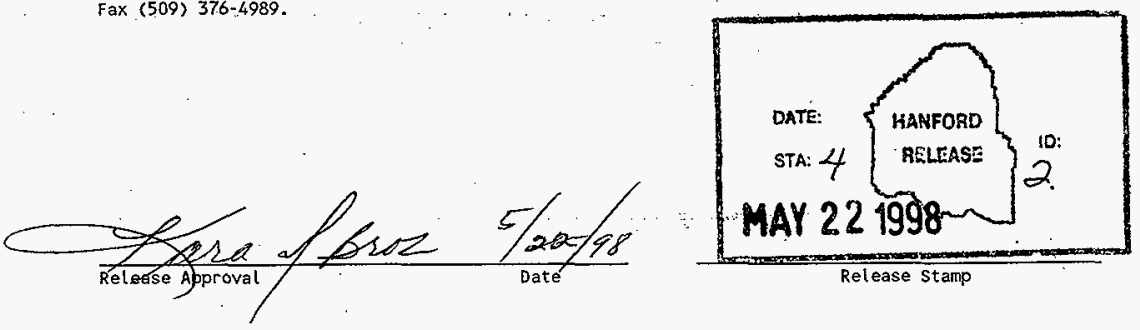

Approved for Public Release 


\section{TABLE OF CONTENTS}

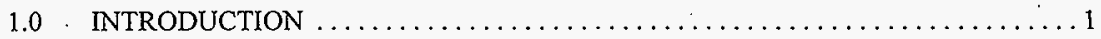

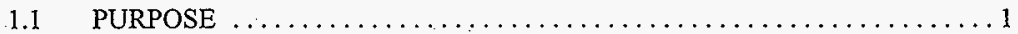

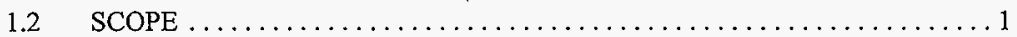

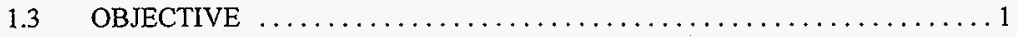

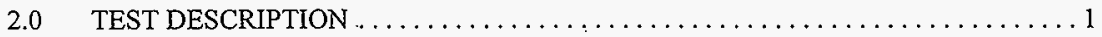

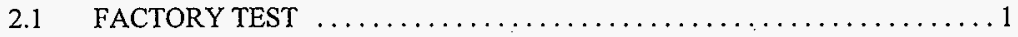

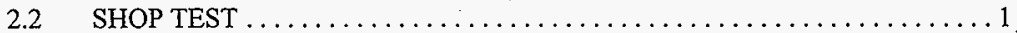

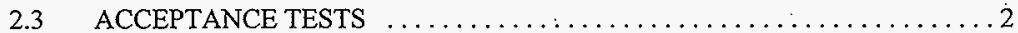

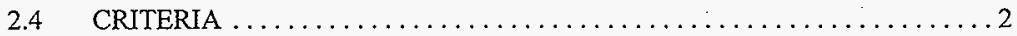

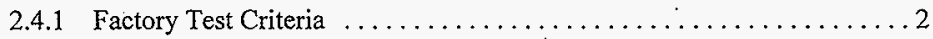

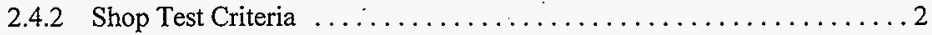

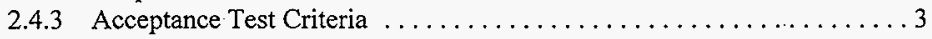

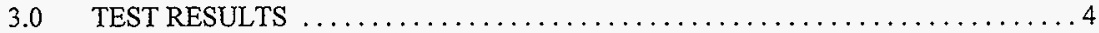

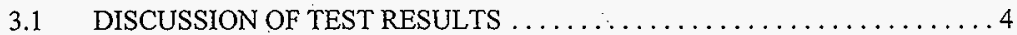

3.2 DISCUSSION OF TEST EXCEPTIONS $\ldots \ldots \ldots \ldots \ldots \ldots \ldots \ldots \ldots$

3.2.1 WHC-SD-W320-OTP-005 Exception $1 \ldots \ldots \ldots \ldots \ldots \ldots \ldots \ldots$

3.2.2 WHC-SD-W320-OTP-005 Exception $2 \ldots \ldots \ldots \ldots \ldots \ldots \ldots$

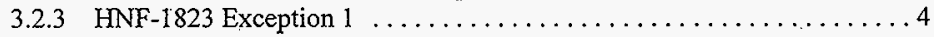

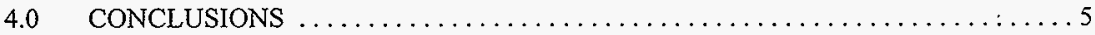

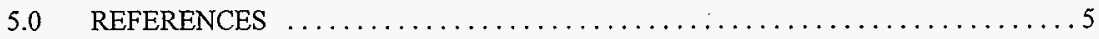

ATTACHMENT 1

COMPLETED COPY OF

MANUFACTURER'S FACTORY TEST $\ldots \ldots \ldots \ldots \ldots \ldots \ldots \ldots \ldots \ldots$ Al-1

ATTACHMENT 2

COMPLETED COPY OF

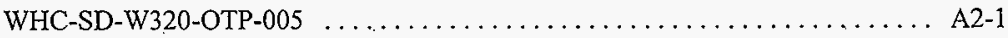

\section{ATTACHMENT 3}

COMPLETED COPY OF

HNF-1823 
HNF-1824, Rev. 0

\subsection{INTRODUCTION}

\subsection{PURPOSE}

This document presents the results of Acceptance Testing of the 241-C-106 in-tank video camera imaging system. This camera system was acquired from R.J. Electronics under Purchase Order MGS-XDV-422215. The purpose of this imaging system is to monitor the Project W-320 sluicing of Tank 241-C-106.

\subsection{SCOPE}

Testing of the 241-C-106 camera system was performed in accordance with WHC-SD-W320-OTP-005, "Tank 241-C-106 In-Tank Imaging System ATP/OTP", and, HNF-1823, "Acceptance Test Procedure for the Tank 241-C-106 In-Tank Imaging System". This document reports the results of that testing.

\subsection{OBJECTIVE}

The objective of acceptance testing of the 241-C-106 video camera system was to verify that all equipment and components function in accordance with procurement specification requirements and original equipment manufacturer's (OEM) specifications.

\subsection{TEST DESCRIPTION}

\subsection{FACTORY TEST}

The W-320 Project in-tank imaging system was tested by the manufacturer prior to shipment, and was witnessed by Lockheed Martin Hanford Company engineering personnel (formerly Westinghouse.Hanford Company). All items required by the contract were inventoried, mechanical and electrical functions were satisfactorily demonstrated, image quality was verified, and in-tank assembly component dimensions were checked.

A completed copy of the manufacturers test report is included as Attachment 1 to this document.

\subsection{SHOP TEST}

Shop testing of the in-tank imaging system was performed on all equipment following receipt from the vendor. The shop tests were performed at the 306E Facility in accordance with Section 7.0 of WHC-SD-W320-OTP-005. The main purpose for shop testing of the imaging system was to re-verify that all assembly components remained functional and that image quality remained acceptable following shipment from the vendor. 
HNF-1824, Rev. 0

Following completion of all shop testing, the Flammable Gas Justification for Continued Operation (JCO) was issued. The camera system was modified on an emergency basis to bring it into compliance with the JCO and resulting Standing Orders. Modifications to the camera system were then shop tested in accordance with WHC-SD-W320-OTP-005, Addendum A.

A completed copy of WHC-SD-W320-OTP-005, including Addendum A, is included as Attachment 2 to this document.

\subsection{ACCEPTANCE TESTS}

Formal acceptance testing of the in-tank imaging system was performed at C-Farm immediately prior to and following installation of the in-tank assembly in riser 7 of Tank 241-C-106. Acceptance testing was performed in accordance with HNF-1823.

A completed copy of HNF-1823 is included as Attachment 3 to this document.

\subsection{CRITERIA}

\subsubsection{Factory Test Criteria}

Factory testing was performed at the imaging system vendor's location. Factory test criteria included:

- a checklist to ascertain that all items and documents required for the contract were supplied

- mechanical system functional checks for the lighting controllers, pan and tilt assembly, and washdown system

- component interface verifications, and in-tank assembly maximum diameter verification

- electrical system functional checks for all camera electrical components including all cables, electric motor noise (interference) tests, camera and lens functions, and picture quality verifications

\subsubsection{Shop Test Criteria}

Shop testing was performed in the 306E facility in accordance with Section 7.0 of WHC-SDW320-OTP-005 as a prerequisite to formal acceptance testing. The 306E facility provided a large indoor area with controlled lighting where image quality checks could be performed. The entire imaging system, including the in-tank assembly, local control console, and master control panel 
HNF-1824, Rev. 0

were set up and interconnected using the system cabling. The in-tank assembly was connected to facility compressed nitrogen and water to test the gas distribution system and washdown system. Criteria for the Shop Tests included:

- master control station component tests (monitor, VCR, and character generator) per original equipment manufacturer's recommendations

- camera lens motors testing for zoom, iris, and focus functions

- camera image resolution and color resolution verification

- pan-and-tilt unit range of motion verification

- camera system lights operability and independent variability

- testing of all system cables

- gas distribution system check valve function

- camera washdown system function

After Section 7.0 of WHC-SD-W320-OTP-005 was completed, the camera system was modified to bring it into compliance with the Flammable Gas Justification for Continued Operation (JCO) and resulting Standing Orders. Addendum A was added to WHC-SD-W320-OTP-005 to document shop testing of the imaging system modifications. Criteria for the imaging system modification testing included:

- verifying purge gas pathway through the pan-and-tilt enclosure

- purge gas pressure and flow interlocks functions

- purge cycle timer adjusted correctly

\subsubsection{Acceptance Test Criteria}

Acceptance testing of the imaging system was performed in the 200 East Area at C-Farm in - accordance with HNF-1823 immediately prior to installation of the in-tank assembly into Riser 7 of Tank 241-C-106. All other system components had previously been installed. Criteria for Acceptance Testing were the same as for Shop Testing except that image resolution verifications consisted only of on-screen verification that image defects were absent. Color charts and resolution charts were not used due to the presence of ambient sunlight at the outdoor C-Farm location. 
HNF-1824, Rev. 0

\subsection{TEST RESULTS}

\subsection{DISCUSSION OF TEST RESULTS}

All testing of the 241-C-106 in-tank imaging system was completed satisfactorily. There were three exceptions discovered during testing, one of which was procedural. These exceptions are discussed in the next section.

Completed copies of all test procedures are found in Attachments 1,2, and 3 of this document.

\subsection{DISCUSSION OF TEST EXCEPTIONS}

\subsubsection{WHC-SD-W320-OTP-005 Exception 1}

During the Shop Testing phase of WHC-SD-W320-OTP-005, step 7.8.3, it was discovered that the camera washdown system did not perform as desired. This was determined to be caused by the manufacturer's use of inadequately sized tubing to carry the washdown water from the upper junction box connector to the spray nozzles. This was noted as Exception 1. Altered Item drawing H-14-100833 was subsequently prepared and released to replace the manufacturer's 1/4" tubing with $1 / 2$ " tubing and fittings. Following this alteration the camera washdown system was determined to function acceptably and Exception 1 was resolved.

\subsubsection{WHC-SD-W320-OTP-005 Exception 2}

WHC-SD-W320-OTP-005 was written to be a combined Shop Test/Acceptance Test/Operational Test Procedure. Following completion of the shop testing portions (Section 7.0 and Addendum A) there was a delay of nearly two years before the camera was delivered to C-Farm for acceptance testing and installation. During this period it was determined that a stand alone Acceptance Test Procedure was required for comparability with site procedure format requirements. Therefore, HNF-1823, "Acceptance Test Procedure for the Tank 241-C-106 InTank Imaging System", was written and released. A new Operational Test Procedure, OTP-320005, "Tank 241-C-106 In-Tank Imaging System Operational Test Procedure", was written and released for the same reason.

Exception 2 in WHC-SD-W320-OTP-005 notes this fact and was resolved by lining out Sections 8.0,9.0. and 10.2 of that document.

\subsubsection{HNF-1823 Exception 1}

During performance of HNF-1823, step 7.1.20, it was discovered that the specified minimum purge cycle time of 23 minutes was not met. The timers in the Hazardous Location Power Controller (HLPC) switched power to the in-tank assembly after a purge cycle of 22.25 minutes. 
HNF-1824, Rev. 0

The National Fire Protection Association NFPA 496-93 specifies that enclosures containing electric motors located in hazardous locations must have ten enclosure volumes exchanged during the purge process before energizing the motors. The manufacturer's test data for the HLPC indicates that a minimum flow rate of $0.9 \mathrm{scfm}$ is necessary prior to flow switch energization. A 23 minutes purge cycle time was calculated based on this minimum flow rate. Test Exception 1 noted this discrepancy.

During Shop Testing of the camera system modifications in WHC-SD-W320-005, Addendum A, step 3.4.4, the minimum flow rate for activation of the flow switch in the HLPC was measured to be $1.1 \mathrm{scfm}$. Using that actual flow rate the minimum required purge cycle time was calculated to be only 18.6 minutes and Exception 1 was resolved.

\subsection{CONCLUSIONS}

All testing of the W-320 Project Tank 241-C-106 imaging system was successfully completed. This equipment is ready for Operational Testing and turnover.

\subsection{REFERENCES}

H-2-818590, Sh. 1

H-2-818690, Sh. 1

H-14-100833

HNF-1823

JCS\#2E-97-2230

OTP-320-005

VI No. 22668, Supp. 105

WHC-SD-W320-OTP-005
Operator Control Station Plan

C-Farm In-Tank Imaging (CCTV)

Camera Mast System Altered Item

Acceptance Test Procedure for the Tank 241-C-106 In-Tank Imaging System

Job Control System Work Package, C-106 In-Tank Imaging (CCTV) Installation

Tank 241-C-106 In-Tank Imaging System Operational Test Procedure

Vendor Information, In-Tank Imaging System

Tank 241-C-106 In-Tank Imaging System ATP/OTP 
HNF-1824, Rev. 0

\section{ATTACHMENT 1 \\ COMPLETED COPY OF \\ MANUFACTURER'S FACTORY TEST}

Al-1 
HNF-1824, Rev. 0

A1-2

WASTE TANK 241-C-106 SYSTEM

P.O. \# MGS-XDV-422215

S.O. \# 594

TEST AND INSPECTION SCHEDULE 
HNF-1824, Rev. 0

WESTINGHOUSE HANFORD CONTRACT \# MCE-XCV-333982

S.O. \# 594

VIDEO TANK INSPECTION SYSTEM

TEST AND INSPECTION SCHEDULE

$\underline{241-C-106}$

Checked

$\underline{\text { R.J. }}$

W.H.

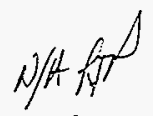

CABLES AND CONNECTORS

- (a) $1 \times 450 \mathrm{ft}$ R4404 control cable assembly.

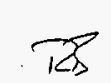

- (b) $1 \times 10 \mathrm{ft.}$ R12364 cable assembly.

- (c) $1 \times 5 \mathrm{ft}$ R7504 cable assembly.

- (d) $1 \times 25 \mathrm{ft} .09810$ light cable assembly.

- (e) $1 \times 25 \mathrm{ft}$ R8504 pan and tilt cable assembly.

- (f) $1 \times 25 \mathrm{ft}$ R12364 camera cable assembly.

- (g) $1 \times$ R8504 mast light cable assembly.

- (h) $1 \times$ R8504 position cable assembly.

(i) $1 \times$ R12364 mast camera cable.

- (j) $1 \times 7 \mathrm{ft} . \mathrm{R} 8504$ lower mast light cable.

- (k) $1 \times 6.5 \mathrm{ft}$. lower mast camera cable.

- (l) $1 \times 4 \mathrm{ft}$ R8504 lower mast pan and tilt cable.
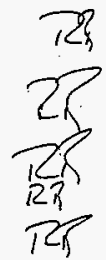

त?

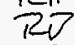

R2

Rद?

Ris

$R 3$

Ri3

23

795.

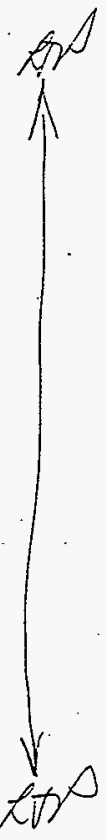


-3-

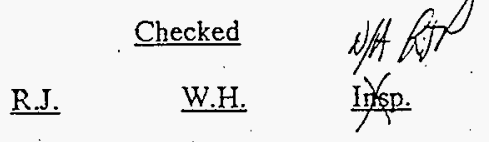

MAST AND CAMERA HEAD COMPONENTS

(a) Camera assembly, type RCS-521-RA.

(b) Camera positioning system - PTE-300-S.

(c) Gas relief valve on camera.

(d) Stainiess steel lighting array with $4 \times 250$ watt pre-focused lights.

(e) Upper mast assembly, junction box and cover plate.

(f) "Garlock 3000" gaskets.

(g) Shield plate.

(h) Riser flange bolt sets.

(i) Riser Flange mating plate.

(j) Drying gas distribution system.

(k) Camera window wash down system.

(l) Light wash down system.
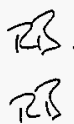

Ris.

Rी

Rी

R

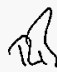

Rs

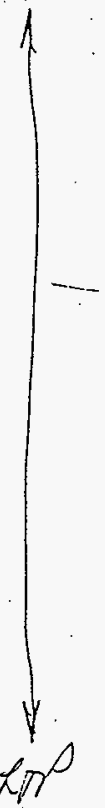

\section{LOCAL CONTROL CONSOLE COMPONENTS}

(a) Local interface unit.

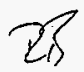

(b) Pan, tilt and zoom lens local control panel with S-video and N.T.S.C. video outputs.
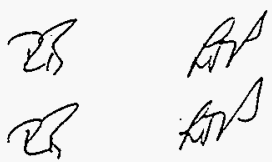

(c) Camera and light wash down solenoid enclosure. 


\section{CONTROL EOUIPMENT MASTER}

(a) Monitor - Color 14" S-video rack mount type - Sony $14 \mathrm{~N} 1 \mathrm{U}$ monitor.

(b) $1 \times 19^{\prime \prime}$ rack mount kit for monitor.

(c) AG1980 S-video VTR.

(d) 19" rack mount for AG1980.

(e) Master camera control unit with character overlay generator. C106MACCU.

(f) Keytronic Type E03601QL keyboard.

\section{Checked}

W.H.

R.J.

21.

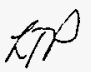

$2 \pi$

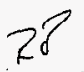

ri
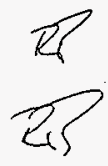

$\ln 1$

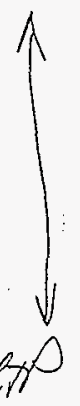

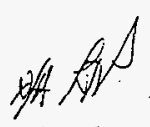

IIxps.

DATA PACKAGE - 5 sets of the following:-

(a) Final drawings.

2,5

$h p^{d}$

(b) Operating manuals.

(c) Maintenance manuals.

Ris

27

27

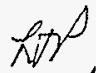

(d) Periodic maintenance specifications.

(e) Recommended spare parts.

(f) OEM specifications/manuals for camera module, lens, VTR and monitors.

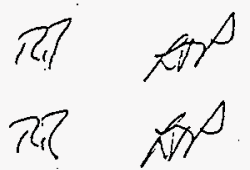


$-5-$

\section{FUNCTIONAL CHECKS - MECHANICAL}

(a) RCS-521 Zoom Camera attached to pan and tilt.

(b) Light array attached to pan and tilt.

(c) Cables and hoses interface.

(d) Tilt operation. $90^{\circ}-0^{\circ}-30^{\circ}$ (range test).

(e) Tilt electronic break holds camera at $+30^{\circ}$.

(f) Pan operation. $175^{\circ}-0^{\circ}-175^{\circ}$ (range test).

(g) Lights operate 1 - 4 .

(h) Pan and tilt interfaces to mast.

(i) Shield plate interfaces to junction box.

(j) Lifting eye.

(k) Gariock 3000 gasket material.

(1) 11 inch maximum diameter check.

Checked

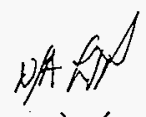

$\underline{\text { R.J. }}$

W.H.

Inoxp.<smiles>C1=CC=C1</smiles><smiles>C1=CC2C=CC(C1)C2</smiles>

R
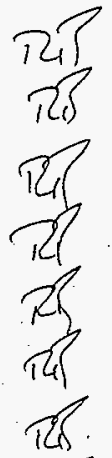

Ril

Rh

Ril.

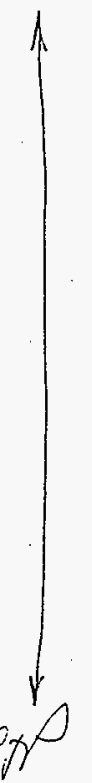


$-6-$

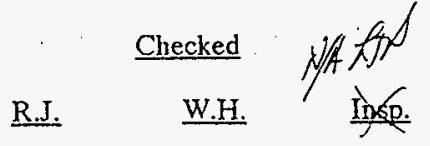

\section{ELECTRICAL - ZOOM CAMERA SYSTEM}

(a) Quality color picture on monitor, at

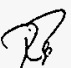
local control area.

(b) Quality color picture on monitor at master control console.

(c) Zoom function operates.<smiles>[K]</smiles><smiles></smiles>

Local/master.

(d) Iris function operates.

Local/master.

(e) Focus function operates.

Local/master.

(f) Pan left/right.

Local/master.

(g) Tilt up/down.

Local/master.
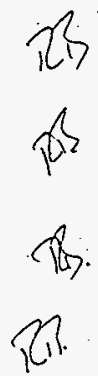

(h) Lights on/off.

Ri.

Local/master.

(i) Light 1 intensity change.

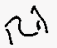

Local/master.

(j) Light 2 intensity change.--

R

Local/master.

(k) Light 3 intensity change.

Local/master.

(I) Light 4 intensity change: Local/master.

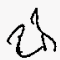<smiles>[AlH2]</smiles><smiles>[C]1CCCCC1</smiles>

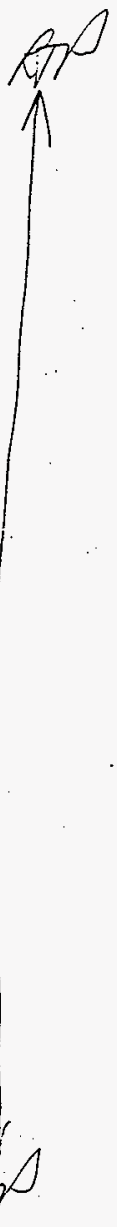


HNF-1824, Rev. 0

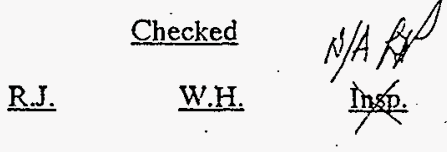

DETAIL FUNCTIONAL CHECKS - ZOOM CAMERA

(a) Zoom moves towards wide angle when operated towards "wide".

(b) Zoom moves towards telephoto when operated towards "tele".

(c) Iris opens when operated towards "open".

(d) Iris closes when operated towards "close".

(e) Focus adjusts to far when operated towards "far".

(f) Focus adjusts to near when operated towards "near".

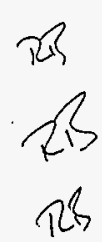

RS<smiles>CC1CCC1</smiles>

kis

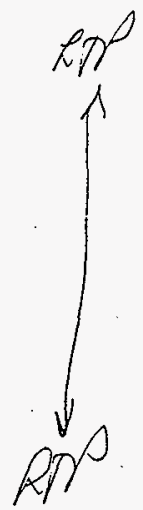

\section{ZOOM CAMERA PICTURE QUALTTY}

With lens suitable focused and stopped down.

Montior display interference-free sharp color image.

(a) Under normal room lighting.
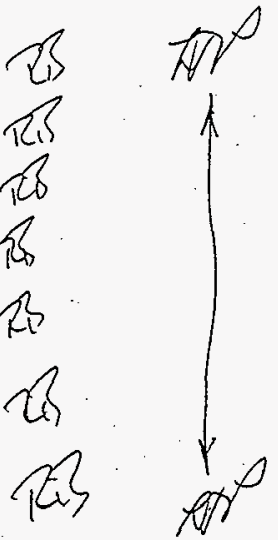

(b) With pan or tilt motor operating.

(c) With zoom motor operating (motor noise test).

(d) W With focus motor operating (motor noise test).

(e) With iris motor operating (motor noise test).

(f) When reviewing a color test chart the color rendition as displayed by the monitor is correct.

(g) Repeat (f) with mast lights operating and room lighting off.

$R$

to

R

R

थ

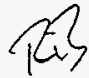


$-8-$

Checked

$\underline{\text { R.J. }}$

W.H.<smiles></smiles><smiles>C1CCC2CCCC(C1)C2</smiles>
adjusted for good picture). Picture is sharp and in focus.

(b) With zoom function set to "tele". an object 12 " from the camera may be brought into sharp focus.

(c) An object $60 \mathrm{ft}$ from the camera may be brought into sharp focus.

PAN AND TILT OPERATION

(a) Tilt operates smoothly and reliabjy.

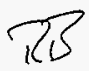

(b) Pan operates smootbly and reliably.

(c) Pan speed varies. Local/master.

(d) Tilt speed varies. Local/master.<smiles>Cl[C]1CCC2CCC1C2</smiles>

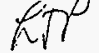<smiles>C1=CC2CCC(C1)C2</smiles><smiles></smiles>

CAMERA AND LIGHT WASH DOWN SYSTEM

(a) Operates from local control panel.

(b) Operates from master control panel.

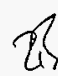

Ris

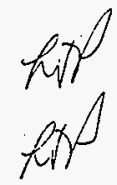

MISCELLANEOUS

Welding Inspection Report.<smiles>[C+]1CCCCC1</smiles> 
HNF-1824, Rev. 0

A1-10

$-9-$

I certify the Video Tank Inspection System has been inspected and has passed all the attached test requirements.

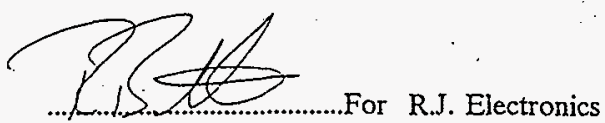

I have conducted/witnessed all the attached tests and accept the system in good working order except as noted.

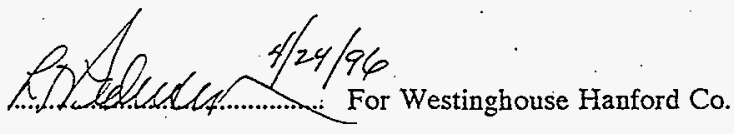

I have conducted/witnessed all the attached tests and accept the system in good working order except as noted.

For Westinghouse Hanford Co. 
HNF-1824, Rev. 0

Al-11

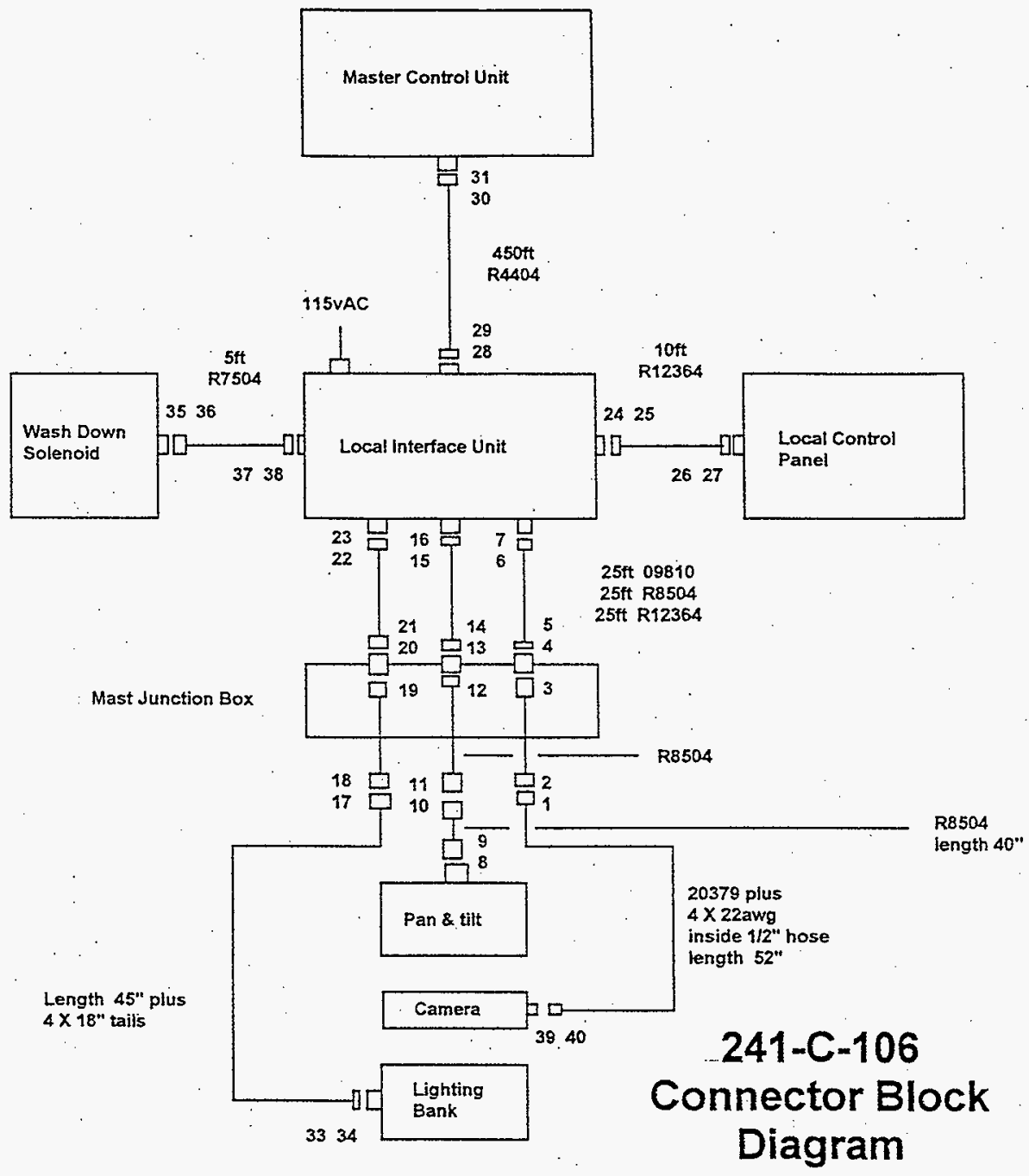


Supptier

HANARD MACHINE, INC.

INSPECTION BYSTECE HAUBY

AWS APPROVEDD BY

DATE $3-31 \div$

SET UP DATA

\section{STEPEEX KMABY}

85128331

\section{Citi}

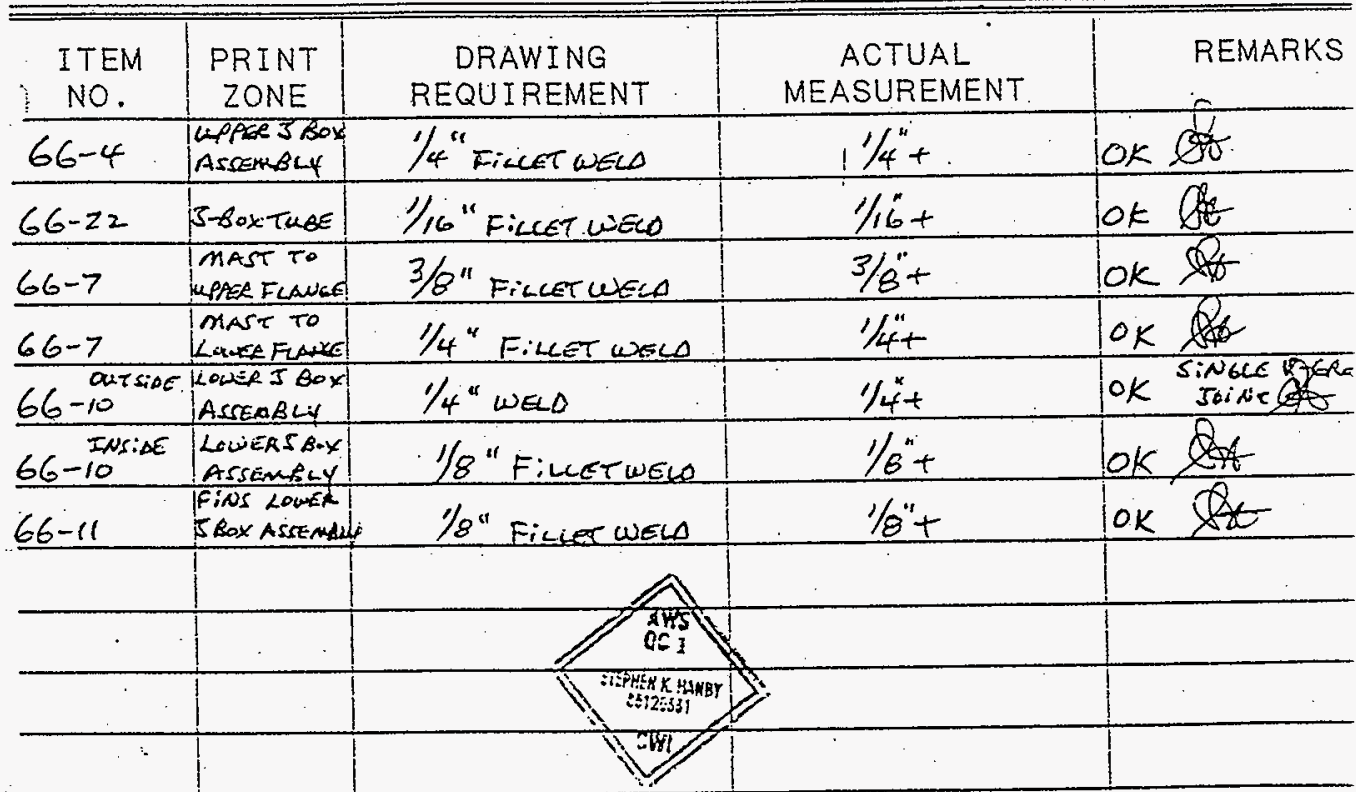

ALC weLAS CONFORA TR Aas 01.1-94 SECTIDN 10.17.1 Turuchat stricherases 
HNF-1824, Rev. 0

ATTACHMENT 2

COMPLETED COPY OF WHC-SD-W320-OTP-005 

2. To: (Receiving Organization)
Distribution

5. Proj./Prog./Dept./Div.:

$W-320$

8. Originator Remarks:

ETN-96-0004
3. From: (originating organization)

Instrument Systems

Integration $/ 74430$

6. cog. Engr.:

LT Pedersen
4. Related EDT No.:

$N / A$

7. Purchase order No.:

$N / A$

9. Equip./Component No.:

$N / A$

10. System/Bldg./Facility:

\section{$241-C-106$}

12. Major Assm. Dwg. No.:

N/A

13. Permit/Permit Application No.: $N / A$

14. Required Response Date: $N / A$

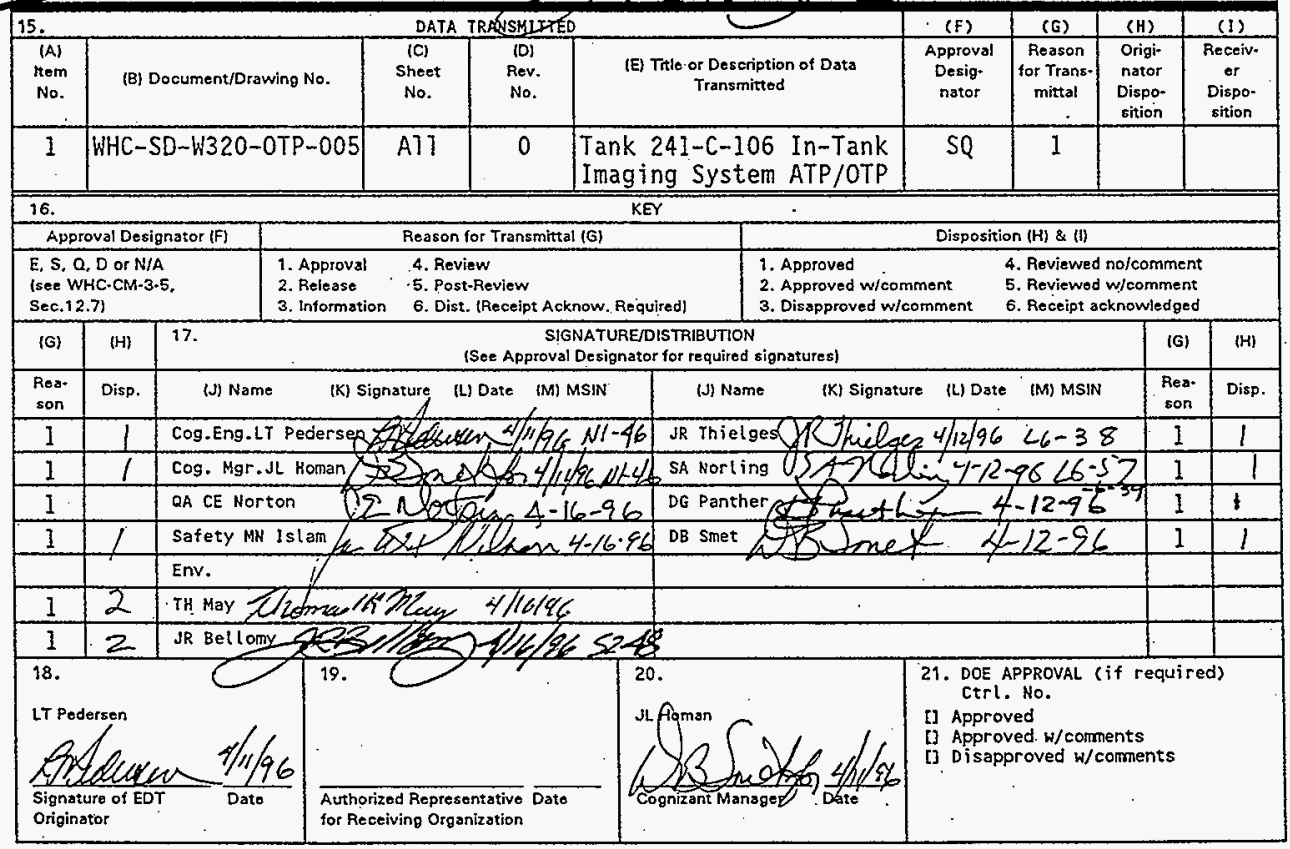

BD -7400-172-2(04/94) GEF097 


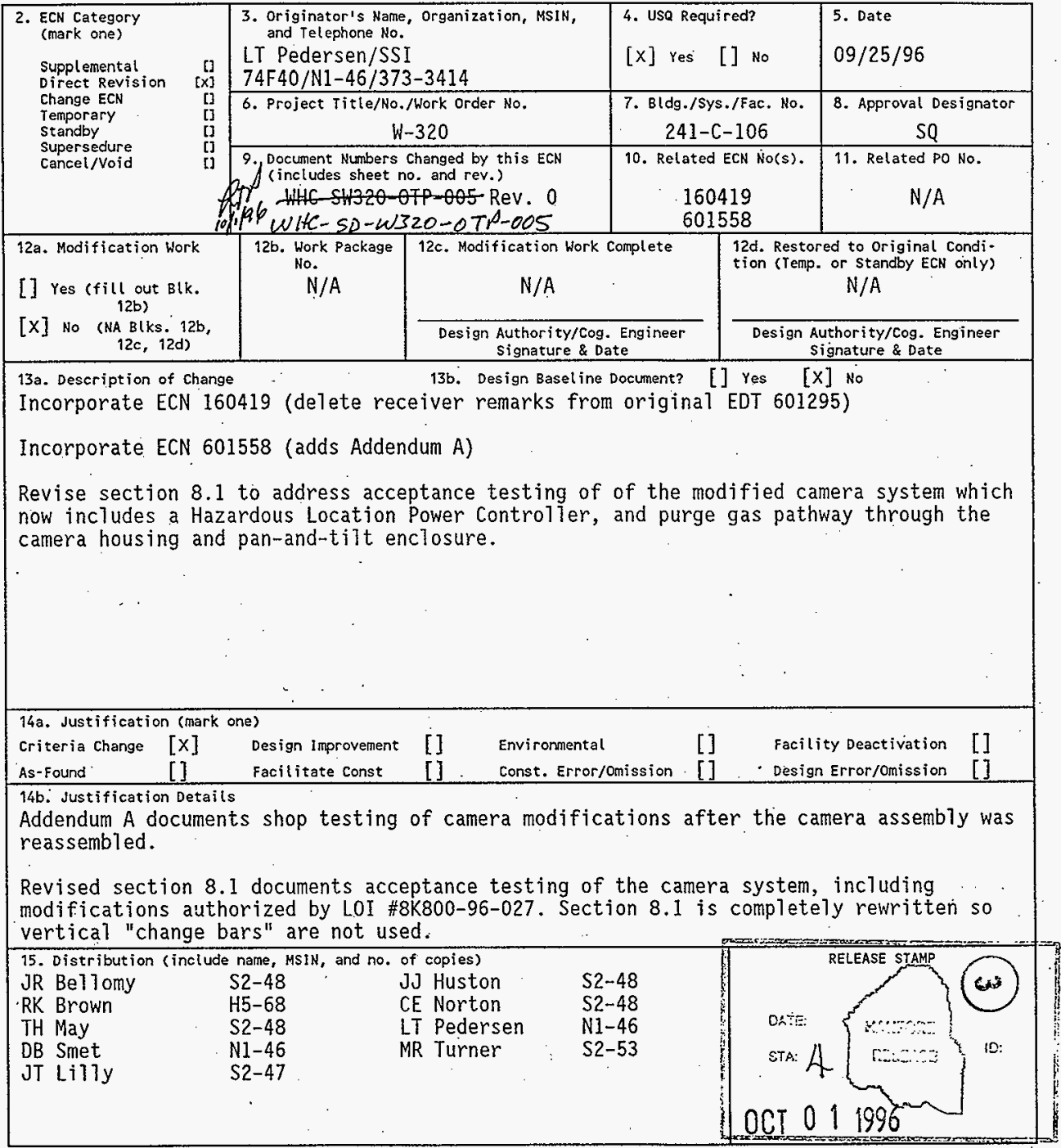




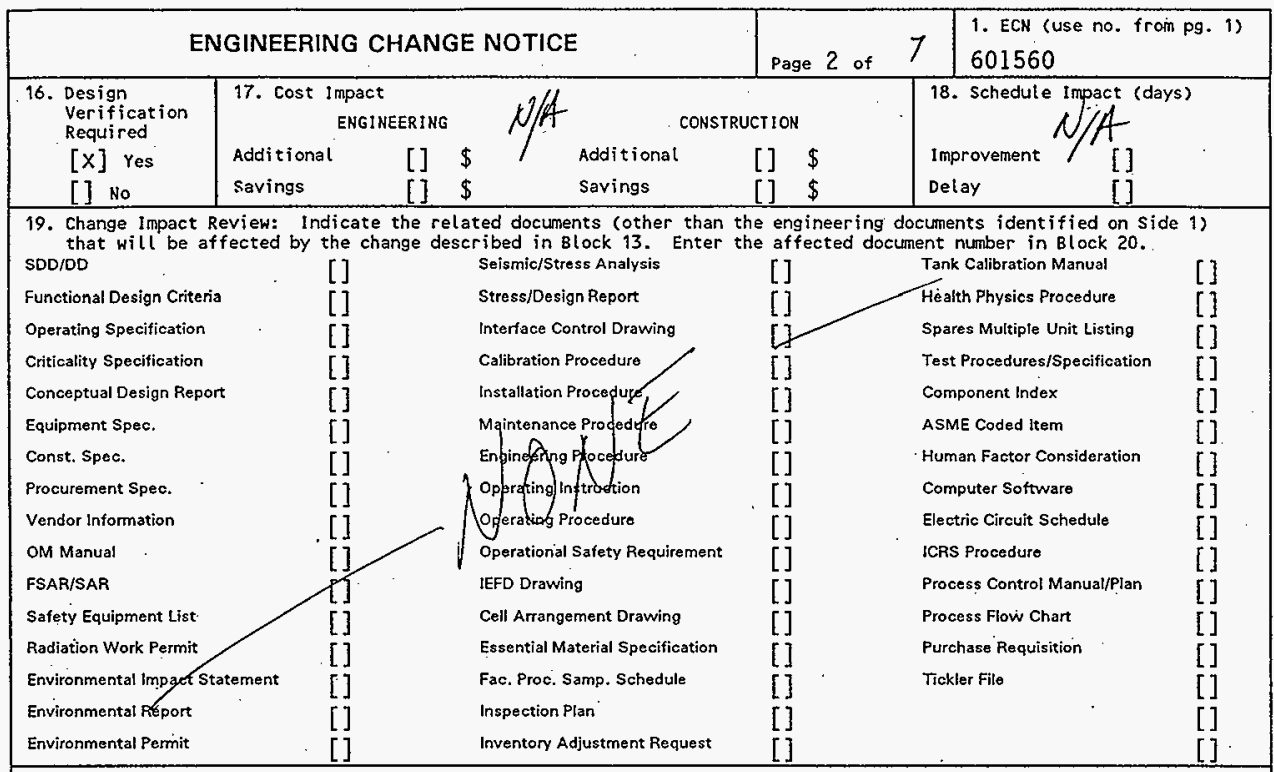

20. Other Affected Documents: (NOYE: Documents listed below will not be revised by this ECN.) Signatures below indicate that the signing organization has been notified of other affected documents $l$ isted below. Document Number/Revision Docunent Number/Revision Docunent Number Revision NONE

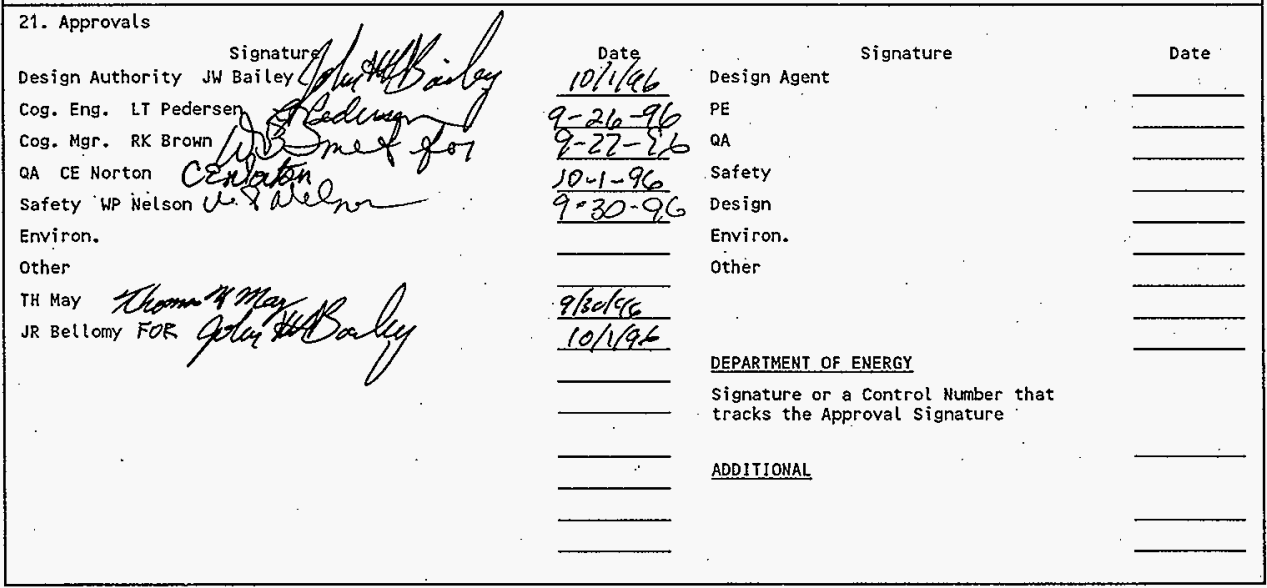




\section{Tank 241-C-106 In-Tank Imaging System ATP/OTP}

LT Pedersen/ST Hamp

Westinghouse Hanford Company, Richiand, WA 99352

U.S. Department of Energy Contract DE-AC06-87RL10930

coln

DOIIILEDT/ECN:

Org Code: 74430

B\&R Code: EW3130010

UC: 506 .

Charge Code: D2MBP

Total Pages: 28

Key Words: Tank 241-C-106, Project W-320, In-Tank Imaging, Camerà

Abstract: This procedure describes and documents the acceptance and operational testing of the 241-C-106 In-Tank Imaging System. This imaging system will be installed in tank 241-C-106 to monitor Project $W-320$ sluicing.

TRADEMARK DISCLAIMER. Reference herein to any specific comercial product, process, or service by trade name, trademark, manufacturer, or otherwise, does not necessarily constitute or imply its endorsement, recommendation, or favoring by the United States Government or any agency thereof or its contractors or subcontractors.

Printed in the United States of America. To obtain copies of this document, contact: WHC/BCS Document Control Services, P.O. Box 1970, Mailstop H6-08, Richland WA 99352, Phone (509) 372-2420; Fax (509) 376.4989 .
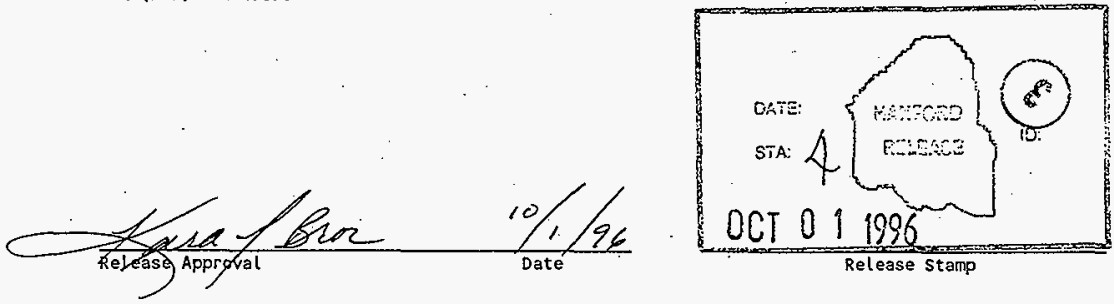


\section{RECORD OF REVISION}

(1) Document Number

WHC-SD-W320-OTP005

(2) Title

Tank 241-C-106 In-Tank Imaging System ATP/OTP

CHANGE CONTROL RECORD

\begin{tabular}{|c|c|}
\hline Revision & Description of Change - Replace, Add, and Delete Pages \\
\hline 0 & Initial Release (EDT 601295) \\
\hline $0-A \quad R S$ & $\begin{array}{l}\text { 1) Incorporate ECN } 160419 \text { (ful1 approval) } \\
\text { 2) Incorporate ECN } 601558 \text { (add Addendum A) } \\
\text { 3) Replace SD page } i \text {; replace SD pages } \\
11,12,13 \text {; add pages } 22-26 \text { (ECN 601560) }\end{array}$ \\
\hline
\end{tabular}

\begin{tabular}{|c|c|}
\hline \multicolumn{2}{|c|}{ Authorized for Release } \\
\hline (5) Cog. Engr. & (6) Cog. Mgr. \\
\hline LT Pedersen & RK Brown \\
\hline $\begin{array}{l}\text { LT Pedersen } \\
\text { Prquaker } \\
\text { Tyeqos }\end{array}$ & 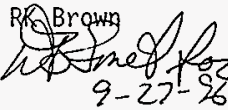 \\
\hline
\end{tabular}

\begin{tabular}{|c|c|c|}
\hline & & \\
\hline & $\cdot \cdot$ & \\
\hline & & \\
\hline
\end{tabular}




\section{TABLE OF CONTENTS}

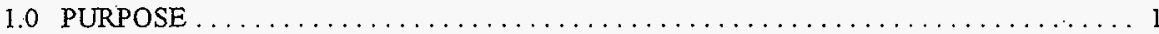

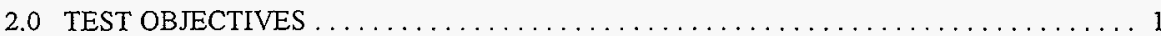

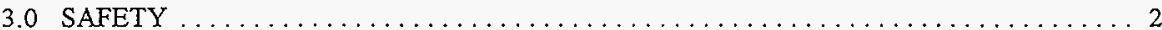

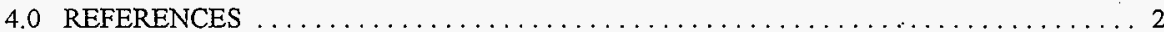

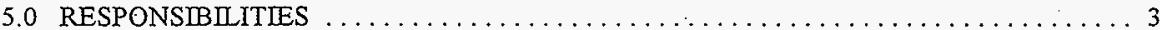

5.1 SURVEILLANCE SYSTEMS INTEGRATION $\ldots \ldots \ldots \ldots \ldots \ldots \ldots \ldots \ldots$

5.2 TEST WITNESSES . . . . . . . . . . . . . . . . . . . . . . . . 3

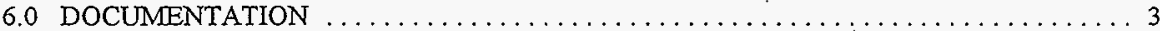

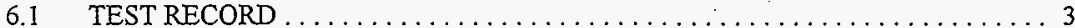

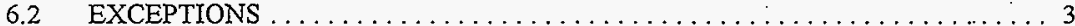

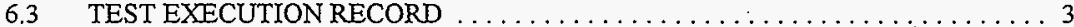

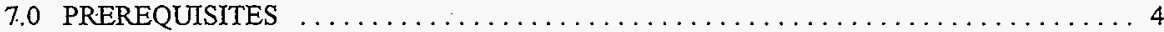

-7.1 SHOP TEST MASTER CONTROL STATION EQUIPMENT $\ldots \ldots \ldots \ldots \ldots \ldots 4$

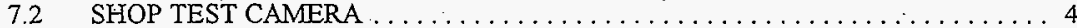

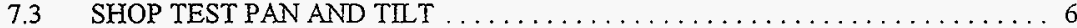

7.4 SHOP TEST CONTROL STATIONS $\ldots \ldots \ldots \ldots \ldots \ldots \ldots \ldots \ldots \ldots \ldots \ldots \ldots$

7.5 SHOP TEST LIGHTS $\ldots \ldots \ldots \ldots \ldots \ldots \ldots \ldots \ldots \ldots \ldots \ldots \ldots$

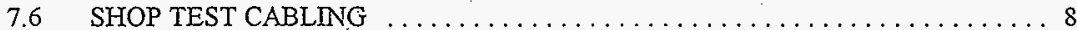

7.7. SHOP TEST CAMERA GAS DISTRUBUTION SYSTEM AND CHECK VALVE .. 9

7.8 SHOP TEST WASHDOWN SYSTEM $\ldots \ldots \ldots \ldots \ldots \ldots \ldots \ldots \ldots \ldots \ldots$

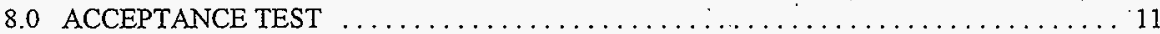

8.1 ACCEPTANCE TEST CAMERA ELECTRICAL, COMPRESSED AIR, WATER,

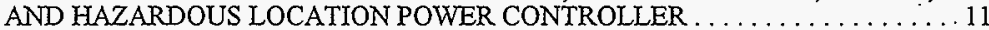

8.2 ACCEPTANCE TEST CAMERA SYSTEM CONTROL - MASTER CONTROL

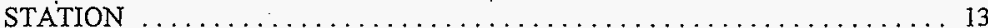

8.3 ACCEPTANCE TEST CAMERA SYSTEM CONTROL - LOCAL CONTROL

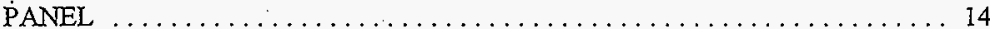

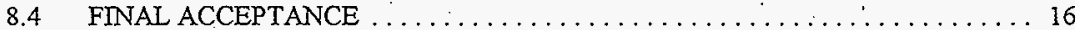

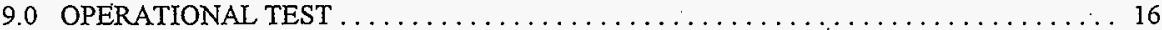

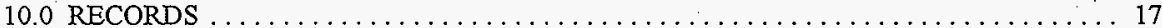

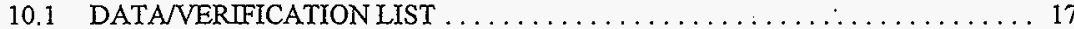

10.2 TEST EXECUTION RECORD $\ldots \ldots \ldots \ldots \ldots \ldots \ldots \ldots \ldots \ldots \ldots \ldots$

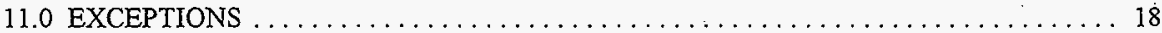

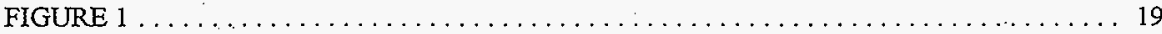

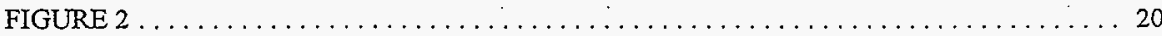

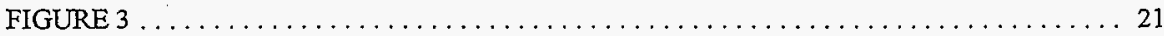

ADDENDUM A $\quad$ SHOP TEST PAN-AND-TILT MODIFICATIONS $\ldots \ldots \ldots \ldots \ldots \ldots 22$ 
WHC-SD-W320-OTP-00S, REV. 0

\section{Tank 241-C-106 \\ In-Tank Imaging System ATP/OTP}

\subsection{PURPOSE}

This procedure will document the satisfactory operation of the 241-C-106 Video Imaging System. Included in the video imaging system are the camera assembly, master control station, local control panel, and system interconnection cables. The camera assembly consists of the camera mast, pan-and-tilt unit, camera, lights, washdown system, and gas distribution system. The camera assembly will be installed in Tank 241-C-106 to monitor activities during the W-320 Project. See Figure 1 for a diagram of the camera assembly.

The testing portions of this procedure are performed in three separate sections $(7.0,8.0$, and 9.0$)$ identified below:

- Section 7.0, Prerequisites (Shop Test), will be performed in the 306E Building. All components of the camera system, including the camera assembly, controllers, lights, monitor, video tape recorders, cables, and character generator will be assembled and tested. The camera assembly will be lifed with a $306 \mathrm{E}$ Building overhead crane by qualified facility personnel. The shop test will be performed while the assembly is suspended from the crane.

- Section 8.0, Acceptance Test, will be performed at the 200 East Area at the 241-C Tank Farm following installation of the master control station components, cables, and local interface panels. The camera assembly will be lifted by a mobile crane in accordance with an approved procedure. The acceptance test will be performed while the camera assembly is suspended from the crane prior to installation into tank 241-C-106.

- Section 9.0, Operational Test, will be performed following installation of the camera assembly into tank 241-C-106.

\subsection{TEST OBJECTIVES}

The objective of this procedure is to demonstrate and document the acceptance and operability of the 241-C-106 camera system. The camera focus, zoom, and iris remote controls will be functionally tested. The resolution and color rendition of the camera will be verified using standard reference charts. The pan-and-tilt unit will be tested for required ranges of motion, the camera lights and washdown system will be functionally tested.

The master control station equipment, including the monitor, VCR, and character generator will be set up and performance tested in accordance with original equipment manufacturer's specifications.

The camera gas distribution system will be tested to ensure that a cooling/drying gas can be flowed through the camera housing in the event that temperatures in the tank require cooling of the imaging module, or drying of condensation from the camera lens. This test will be performed by attaching the gas input connector, (located in the upper junction box), to a pressurized gas 
supply and verifying that the check valve, (located in the camera housing), opens to exhaust the. compressed gas. Leak tightness of the various gas distribution system fittings will also be verified.

The 241-C-106 camera system will also be qualified in accordance with WHC-SD-GN-PROC20003. This qualification procedure assures acceptable resolution of the camera imaging components utilizing the camera system lights. A Surveillance Systems Integration Test Engineer qualified in accordance with WHC-SD-GN-PROC-20002 will perform the camera system qualification test.

\subsection{SAFETY}

Safety is of primary importance throughout all phases of this procedure. Only the test director, cognizant test engineer, and/or their approved delegate shall operate the camera equipment. A Job Hazard Analysis Checklist and a 306-E Specific Job Hazard Analysis Checklist shall be prepared for the shop test portion of this procedure (Section 7.0), which will be performed in the 306-E Facility. The Job Hazard Analysis will be posted prominently in the area where shop testing is performed. A pre-job safety briefing shall be conducted with all involved test personnel, and documented on the Job Hazard Analysis sign-off sheet. All testing performed in the 306-E Facility shall be conducted in accordance with WHC-IP-0882.

Acceptance and Operational Testing (Sections 8.0 and 9.0) will be performed at C-Farm in the 200 East Area. These tests will be performed immediately prior to camera instaliation, and immediately after camera installation, respectively. The camera installation package (PCP W-320-91) will designate all safety requirements for those portions of this procedure.

H-2-818559, Sh. 3

$\mathrm{H}=2-818561$, Sh. 5

$\mathrm{H}-2-818590$

$\mathrm{H}-2-818690$, Sh. 1

PCP W-320-91

WHC-LP-0882

WHC-S-0439

WHC-SD-W320-TP-001

WHC-SD-GN-PROC-20002

WHC-SD-GN-PROC-20003

\subsection{REEERENCES}

"Project W-320 P\&D Tank 241-C-106

"Project W-320 P\&D TK 241-C-106 HVAC"

"Instrumentation Operator Control Station Plan"

"C-Farm In-Tank Imaging (CCTV)"

"Process Control Package for installation of the Imaging

System into Riser 7 for C-Farm in support of the

W-320 Tank 241-C-106 Sluicing Project"

"306E Building Administration Manual".

"Specification for Procurement of Color Video Imaging

System for Waste Tank 241-C-106"

"Project W-320, Tank 241-C-106 Waste Retrieval Sluicing

System, Testing Plan"

"Qualification of Surveillance Systems Engineering CCTV Operators" $^{\prime \prime}$

"Qualification of CCTV Systems" 
WHC-SD-W320-OTP-005, REV. 0

\subsection{RESPONSIBMITIES}

\subsection{SURVEULANCE SYSTEMS INTEGRATION}

A Surveillance Systems Integration (SSI) Test Engineer shall be responsible for the coordination, scheduling, performance and documentation of the test procedure.

\subsection{TEST WITNESSES}

Tank Farm Operations and Quality Control will provide a representative to witness the satisfactory completion and approval of pertinent steps identified in this procedure. Witnesses are responsibie for verifying that organizational requirements are met throughout the testing and documentation sequences of the procedure.

\subsection{DOCUMENTATION}

\subsection{TEST RECORD}

All personnel involved in the performance of this test, inciuding the SSI Test Engineer, shall fill - out a line in Section 10.1, Data/Verification List.

Test results shall be recorded by the SSI Test Engineer. Test steps which require the recording of specific data shall be completed by the SSI Test Engineer. The signature(s) of the person(s) accepting the test sections will be entered in the appropriate place following the test section indicating compliance with the stated requirements or the successful completion of the given test steps. Unacceptable conditions or readings are to be recorded in Section 11.0, Exceptions.

The SSI Test Engineer will maintain a chronological test log documenting when various phases of the test are conducted and any pertinent information not recorded in the test procedure.

\subsection{EXCEPTIONS}

Exceptions by step number, and other notes, are to be recorded in Section 11.0. This section must be dispositioned (including the generation of any required ECNs) and signed off prior to final ATP/OTP acceptance. If no exceptions are encountered, this section may be so noted and closed out by the SSI Test Engineer.

During the performance of this test, errors in text may be encountered which require correction/adjustment to complete the test. The correction is to be noted in the ATP/OTP and listed as an exception in Section 11.0.

\subsection{TEST EXECUTION RECORD}

The final acceptance of the ATP/OTP results shall be indicated by signatures listed under Section 10.2, Test Execution Record. 


\subsection{PREREQUISITES}

NOTE: During the shop test the SSI Test Engineer will verify each camera control is satisfactory and will initial in the space provided to signify completion. The SSI Test Engineer will also sign off in the space provided at the end of each section. The sequence of steps in the shop test section may be altered at the discretion of the SSI Test Engineer.

\subsection{SHOP TEST MASTER CONTROL STATION EQUIPMENT}

7.1.1 Verify that the lighting system is operable from the master control panel and from the local control console. (Watch for noise while panning/tilting) SSI Engineer Initials_fff

7.1.2 Set up S-VHS color monitor in accordance with owner's operation manual instructions. Monitor a scene from the test location and verify image quality. SSI Engineer Initials_ff

7.1.3 Set up S-VHS video tape recorder in accordance with owner's operation manual instructions. Record a scene from the test location and verify playback. SSI Engineer Initials

7.1.4 Set up the character generator in accordance with owner's operation manual instructions. Verify that alpha and numeric characters and pointers can be placed on-screen.

SSI Engineer Initials $t+1$

7.1.5 Steps 7.1.1 through 7.1.4 are complete.

SSI Test Engineer: RAdewe Date $5 / 16 / 96$

\subsection{SHOP TEST CAMERA}

7.2.1 Using the camera zoom control, manipulate the zoom control to wide angle. Verify the zoom moves towards wide when operated towards "wide".

SSI Engineer Initials the

7.2.2 Manipulate the zoom control to telephoto. Verify the zoom moves towards telephoto when operated towards "tele".

SSI Engineer Initials

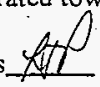


7.2.3 Using the camera iris control, manipulate the iris control to open. Verify that the iris opens when operated towards "open".

SSI Engineer Initials

7.2.4 Manipulate the iris control to close. Verify that the iris closes when operated. towards "close".

SSI Engineer Initials Lfy

7.2.5 Using remote camera focus control, manipulate the focus control to far. Verify that the focus adjusts to far when operated towards "far".

SSI Engineer Initials $\_$,

7.2.6 Manipulate the focus control to near. Verify that the focus adjusts to near when operated towards "near".

SSI Engineer Initials

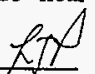

7.2.7 Verify that camera will focus on objects in the range of 3 feet to infinity. SSI Engineer Initials<smiles>CC12CCCC(C3CC3)C1C2</smiles>

7.2.8 Focus the camera on a standard resolution chart. Adjust the lens or camera distance so that the border of the chart just fills the monitor display. Observe the converging black and white lines near the center of the chart. Determine the point at which the individual vertical lines become indistinct. The numbers at the sides of the converging lines correspond to the number of TV lines resolved at that point. Record the number which corresponds to the locations where the vertical lines become indistinct.

NOTE: Horizontal resolution is expressed in terms of the vertical dimension of the picture. Therefore, the horizontal resolution number (measured by the vertical lines on the chart) must be multiplied by $4 / 3(1.33)$ to obtain the actual number of resolvable horizontal lines.

Horizontal resolution number:

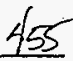

SSI Engineer Initials

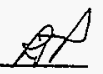

7.2.9. Verify that the horizontal resolution equals or exceeds $400 \mathrm{TV}$ lines.

SSI Engineer Initials

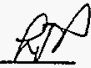


7.2.10 While the camera is focused on the standard resolution chart, verify that the picture is free of image defects such as ghost images, picture lag, distortion, hum, or smearing.

SSI Engineer Initials

7.2.11 Focus the camera on a standard color reference chart. Adjust the lens or camera distance so that the border of the chart just fills the monitor display. Simultaneously view the monitor and the chart. Verify colors are accurately rendered on the monitor display.

SSI Engineer Initials

7.2.12 Steps 7.2.1 through 7.2.11 are complete.

SSI Test Engineer: Etheduker Date_5/16/96

\subsection{SHOP TEST PAN AND TMT}

7.3.1 : Verify that the pan-and-tilt feedback potentiometers are operational and providing position information to the control monitor display.

SSI Engineer Initials

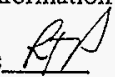

7.3.2 Using the tilt controls, position the camera to horizontal and tilt position display on monitor is $90^{\circ}$. Verify that the electronic brake holds.

7.3.3 Using the pan controls, turn the camera until the pan position display on the monitor is $180^{\circ}$. Verify that the electronic brake holds.

SSI Engineer Initials

7.3.4 Pan the camera clockwise until the stop is reached. Record the pan position readout displayed on the monitor: 000 .

SSI Engineer Initials fffP

7.3.5 Pan the camera counter-clockwise until the stop is reached. Record the pan position readout displayed on the monitor: 359 .

SSI Engineer Initials $\mathscr{L T}$ 
7.3.6 Record the total camera panning capability: $359^{\circ}$

SSI Engineer Initials 270

7.3.7 Verify that camera is capable of panning a minimum of $350^{\circ}$.

SSI Engineer Initials_ $\$ 7$

7.3.8 Using the tilt controls, position the camera to the vertical down position.

Verify that the electronic brake holds. Record the tilt position readout

displayed on the monitor: $18 L$

SSI Engineer Initials LOS

7.3.9 Tilt the camera upward until the stop is reached. Verify that the electronic brake holds. Record the tilt position readout displayed on the monitor: 225 SSI Engineer Initiais th

7.3.10 Record the total camera tilting capability: $156^{\circ}$.

SSI Engineer Initials

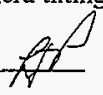

7.3.11 Verify that camera is capable of tilting a minimum of $120^{\circ}$.

SSI Engineer Initials

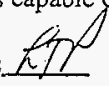

7.3.12 Steps 6.3.1 through 6.3.11 are complete.

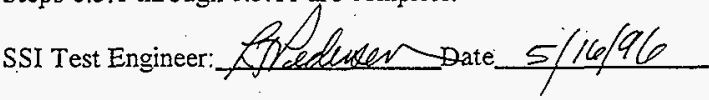

\subsection{SHOP TEST CONTROL STATIONS}

NOTE: In this section it is not necessary to completely repeat the previous sections. The purpose of this section is to verify and document that the system controls function from the local control console as well as from the master control panel.

7.4.1 Attach the S-VHS output on the local control console to a S-VHS monitor utilizing a S-VHS video cable. Verify that the monitor displays a satisfactory color picture.

SSI Engineer Initials

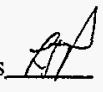


7.4.2 Verify that the lighting system is operable from the master control panel and . from the local control console.

SSI Engineer Initials

7.4.3 Verify that camera controls for focus, zoom, and iris are operable from the master control panel and from the local control console ${ }_{4}$

SSI Engineer Initials_ty

7.4.4 Verify that pan-and-tilt unit is operable from the master control panel and from the local control console.

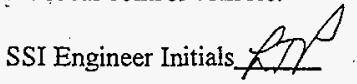

7.4.5 Attach the NTSC output on the local control console to a composite monitor utilizing a coaxial video cable. Verify that the monitor displays a satisfactory color picture.

SSI Engineer Initials

7.4.6 Steps 7.4.1 through 7.4.5 are complete.

SSI Test Engineer: Lftedexen Date $5 / 16 / 96$

\subsection{SHOP TEST LIGATS}

7.5.1 Verify that all four camera system lights are operational, and capable of independent variable intensity.

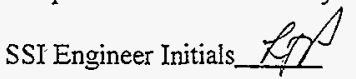

7.5.2 Step 7.5.1 is complete.

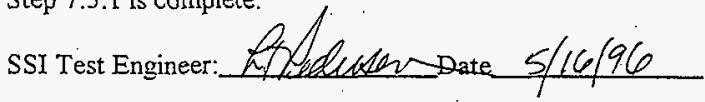

\subsection{SHOP TEST CABLING}

NOTE: In this section it is not necessary to completely repeat the previous sections. The purpose of this section is to verify and document that the system cables are operational.

7.6.1 Verify that all cabling is operational.

SSI Engineer Initials fat 
7.6.2 Step 7.6.1 is complete.

SSI Engineer Initials Test Engineer: the Date $5 / 16 / 96$

\subsection{SHOP TEST CAMERA GAS DISTRIBUTION SYSTEM AND CHECK VALVE}

\section{CAUTION}

For this test the camera gas distribution system will be connected to compressed bottled nitrogen. Extreme care must be exercised when handling compressed gasses. All movement of compressed gas bottles shall utilize approved bottle carts. Only $306 \mathrm{E}$ Facility personnel familiar with the proper use of compressed gasses shall perform this test.

\section{CAUTION}

The check valve in the camera housing is designed to open at 1 to 2.5 psi. Do not pressurize the camera gas distribution system beyond 3 psi if the check valve fails to open.

7.7.1 Set up camera system check valve as shown in Figure $2 \mathrm{a}$ and slowly pressurize the inlet side and record the pressure where bubbles are first noticed (cracking pressure). Do not pressurize the system beyond 3 psi.

Cracking Pressure: 2.5 psig

7.7.2 Verify that check valve "cracking" pressure is 3 psi or less.

SSI Engineer Initials Ap

7.7.3 Bubble test all hoses and fittings, making sure that there are no leaks.

Tighten where necessary.

SSI Engineer Initials

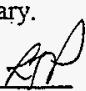


WHC-SD-W320-OTP-005, REV. 0

7.7.4 Verify what minimum pressure/flow provides unobstructed air flow through the camera gas distribution system.

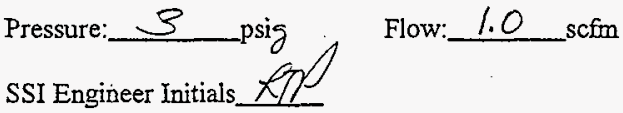

7.7.4 Set up camera system check valve as shown in Figure $2 \mathrm{~b}$ and pressurize to 1 psi. Verify that no bubbles are noticed.

SSI Engineer Initials $x$

7.7.5 Steps 7.7.1 through 7.7.4 are complete.

SSI Test Engineer: Afleecken Date $5 / 17 / 96$

\subsection{SHOP TEST WASHDOWN SYSTEM}

\section{CAUTION}

The camera will be connected to $306 \mathrm{E}$ building water to test the washdown system. To prevent an electrical shock hazard, all electrical connections in the vicinity of the camera assembly must be connected to Ground Fault Circuit Internupter protected receptacles.

7.8.1 Set up camera system washdown system as shown in Figure 3.

SSI Engineer Initials LIP

7.8.2 Mix up a solution of kaolin clay and water to the approximate consistency of thin wet cement. Splatter the solution thoroughly onto the camera viewing window and lights and activate washdown system from master control station.

SSI Engineer Initials

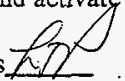

7.8.3 Verify that spray pattern covers the camera viewing window and all four lights. Record length of time required to remove splattered kaolin clay solution from viewing window and lights.

Length of time washdown system ran: * See excrpotion sheef $\# /$. SSI Engineer Initials 
7.8.4 Repeat camera resolution test described in step 7.2.8. Verify that horizontal resolution equals or exceeds $400 \mathrm{TV}$ lines.

SSI Engineer Initials

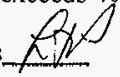

7.8.5 Verify that washdown system can be activated from local control panel.

SSI Engineer Initials 20

7.8.6 Steps 7.8.1 through 7.8.5 are complete.

SsI Test Engineer:AlAedecter $\sim 7 / 17 / 96$

\subsection{ACCEPTANCE TEST}

NOT During the acceptance test the SSI Test Engineer will verify each camera control is atisfactory and will initial in the space provided to signify completion. The SSI Test Ekgineer and witnesses wili aiso sign off in the spaces provided at the end of each section. The sequence of steps in the acceptance test section may be altered at the discretion of the SSI Test Engineer.

\subsection{ACCEPTANCE TEST CAMERA ELECTRICAL, COMPRESSED ARR, WATER,} AND HAZARDOUS LOCATION POWER CONTROLLER

8.1.1 Connet the three (3) 50' camera testing cables (R09810, R8504 and R12364) to the appropriate bulkhead connectors in the camera upper junction box and to the apprepriate connectors located on the underside of the FCU local interface unit. Note: These three cables are for temporary control of the camera, pan-and-tilt, and camera lights. As a safety precaution, each of these cables have different connectors and cannot be accidentally interchanged.)

8.1.2 Connect the 450' R44Q4 camera control cable to the appropriate connector on the underside of the FCQ local interface unit and to the connector on the back of the camera control unit in CP-02. (Note: To prevent improper connection, this cable has connectors which are different from all other system connectors.)

8.1.3 Connect the $10^{\prime}$ R12364 local control cable to the connector on the front face of the local control unit inside the heal control panel enclosure and to the connector on the underside of the FQU local interface unit. (Note: To prevent improper connection, this cable has connectors which are different from all other system connectors.)

8.1.4 Connect the 5' R7504 washdown system cable to the connector on the washdown solenoid enclosure and to the appropriate connector on the FCU local interface unit. (Note: To prevent improper donnection, this cable has connectors which are different from all other system connectors.)

$$
\begin{aligned}
& \text { SeeExpotion sheet } \# 2 \\
& \text { RTP } 4 / 0798
\end{aligned}
$$


8.1.7 Attach the 50' test hose to the camera upper junction box drying/cooling/purge gas system pneumatic quick disconnect coupling and to the air outlet connestor on the HLPC. Open instrument air valve HV13676 (near HLPC).

8.1.8 Verify air pressure is in the range of 30 to $40 \mathrm{psi}$ on the HLPC air pressure gage (on freat inside panel of the HLPC enclosure).

8.1.9 Verify that drying/cooling/purge gas (instrument air) is flowing out of the check valve in the top of the pan-and-tilt housing.

8.1.10 Close process building panelboard breaker for IN-TANK CCTV FCU-1361 C106-PP1/\#6 (ON position). Verify that the GFCI feature of the breaker functions properly via the test and reset buttons.

8.1.11 Close process building pandlboard breaker for GFCI RCPT AT FCU-1361 RACK C106-PPI/\#9 (ON pasition).

8.1.12 Using the VOM, measure and verify the voltage at the FCU receptacle is in the range of 114 to $126 \mathrm{~V}$ ac.

8.1.13 Verify that the GFCI feature of the FCU receptacle functions properly via the test and reset buttons.

8.1.14 Close MO-211 panelboard breaker for CP-02 IN TANK IMAGING RCPTS PNL-MO211/\#3 (ON position).

8.1.15 Using the VOM, measure and verify the voltage at the master control station CP-02 surge suppressor receptacle is in the range of 114 to $126 \mathrm{~V}$ ac.

8.1.16 Connect power cords from CP-02 master control station monitor, VCR, and camera control unit to CP-02 surge suppressor receptacle.

8.1.17 Connect an S-VHS video cable from the CP-02 master control station camera control unit "S-VHS OUT" terminal to the Video Tape Redorder "S-VIDEO INPUT" terminal. Connect an S-VHS video cable from the Wideo Tape Recorder "S-VIDEO OUT" terminal to the monitor "Y/C IN" terminal. 
8.1.18 Connect the CP-02 master control station keyboard to the camera control unit keyboard terminal.

8.1. 9 Start camera purge timing sequence by pressing "RESET" button on front inside panel of HLPC.

8.1.20 Verify that camera purge timing sequence lasts a minimum of 23 minutes.

8.1.21 Verify that red "ENERGIZED" lamp on front inside panel of HLPC comes on, indlcating that power is now available to the camera system.

8.1.22 Using the VOM, measure and verify the line side voltage at the FCU local interface unit disconnect switch, located inside the local interface unit enclosure, is in the range of 114 to $126 \mathrm{~V}$ ac.

8.1.23 Verify that camera washdown system operates from local control panel.

8.1.24 Verify that camera washdown system operates from master control station.

8.1.25 Record serial number of HLPC:

8.1.26 Steps 8.1.1 through 8.1.25are complete and acceptable.

\subsection{ACCEPTANCE TEST CAMERA SYSTEM CONTROL - MASTER CONTROL STATION}

NOTE: The Master Control Station is located in MO-211 (Operator Control Station).

8.2.1 Energize the monitor, video recorder, character generdtor, and camera control unit. Verify these components have power and are operational.

8.2.2 Verify that the lighting system is operational and variable controllers are functioning.

8.2.3 Using pan and tilt controls, pan in the clockwise direction until the stop is reached. Verify that the pan electronic brake holds.

See Exception Sheet\#2 
8.2.4 Pan in the opposite direction until the stop is reached. Verify that the pan electronic brake holds.

8.2.5 Tilt the camera to the vertical down position. Verify that the electronic brake holds.

8.2.6 Tilt camera upward until the stop is reached. Verify that the electronic brake holds.

8.2.7 Manipulate the camera zoom control to wide angle. Verify zoom moves towards wide when operated towards "wide".

8.2.8 Manipulate the camera zoom control to telephoto. Verify zoom moves towards telephoto when operated towards "tele".

8.2.9 Manipulate the ckmera iris control to open. Verify that the iris opens when operated towards lopen".

8.2.10 Manipulate the camera iris control to close. Verify that the iris closes when operated towards "close".

8.2.11 Manipulate the camera focus control to far. Verify that the focus adjusts to far when operated towards "far"'.

8.2.12 Manipulate the focus control to hear. Verify that the focus adjusts to near when operated towards "near".

8.2.13 Steps 8.2.1 through 8.2.12 are complete SSI Test Engineer: Date Operations: Qate QC Representative: Date

\subsection{ACCEPTANCE TEST CAMERA SYSTEM CONTROL - KOCAL CONTROL} PANEL

NOTE: The Local Control Panel is located adjacent to Tank 241-C-106, mounted to the FCU.

8.3.1 Energize all components. Verifying each component for power and operability.

See Exception Sheet $\# 2$ $x / 104 / 27 / 98$ 
WHC-SD-W320:OTP-00S, REV. 0

8.3.2 Attach an auxiliary monitor to the video output of the local control panel. Verify that monitor is operational:

8.3.3 Verify that the lighting system is operational and variable controllers are functioning.

8.3.4 Using pan and tilt controls, pan in the clockwise direction until the stop is reached. Verify that the pan electronic brake holds.

8.3.5 Pan in the opposite direction until the stop is reached. Verify that the pan electronic brake holds.

8.3.6 Tilt the camera to the vertical down position. Verify that the electronic brake holds.

8.3.7 Tilt camera upward until the stop is reached. Verify that the electronic brake holds.

8.3.8 Manipulate the camera zpom control to wide angle. Verify zoom moves towards wide when operated towards "wide".

8.3.9 Manipulate the camera zoom control to telephoto. Verify zoom moves towards telephoto when operated towards "tele".

8.3.10 Manipulate the camera iris control to open. Verify that the iris opens when operated towards "open".

8.3.11 Manipulate the camera iris control to chese. Verify that the iris closes when operated towards "close".

8.3.12 Manipulate the camera focus control to far. Verify that the focus adjusts to far when operated towards "far".

8.3.13 Manipulate the focus control to near. Verify that the focus adjusts to near when operated towards "near".

8.3.14 Steps 8.3.1 through 8.3.13 are complete.

SSI Test Engineer: Operations:

QC Representative:

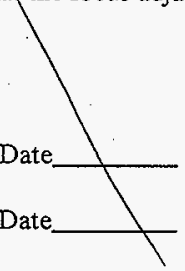
Date

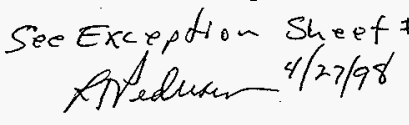




\section{4 \\ FINAL ACCEPTANCE}

Acceptance testing per this procedure is completed satisfactorily and the 241-C-106 Video Camera System is ready for installation and service.

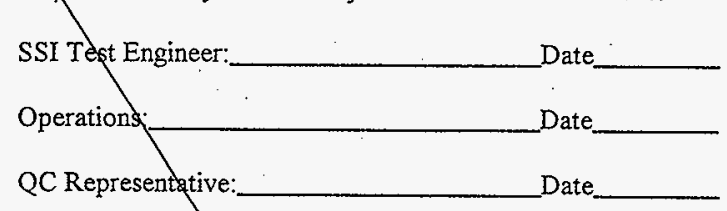

\subsection{OPERATIONAL TEST}

Repeat sections 8.2 and 8.3 of this procedure to ensure that the 241-C-106 Video Camera System is operating satisfactorily after installation of the camera assembly into riser 7 . Any discrepancies found with the 241-C-106 Video Camera System during this section of the ATP/OTP shall be listed as an exception in section 11.0 .

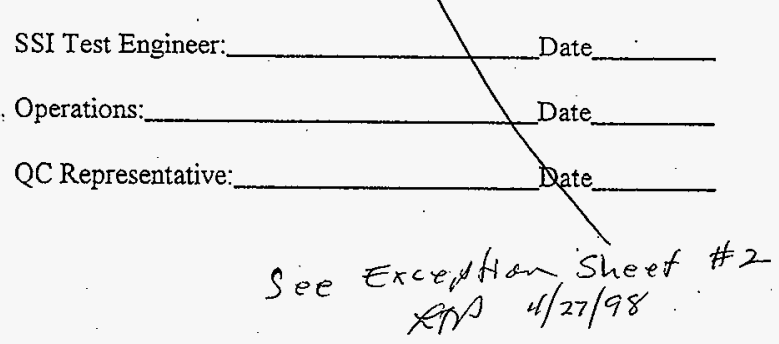




\subsection{RECORDS}

\subsection{DATA/VERIFICATION LIST}

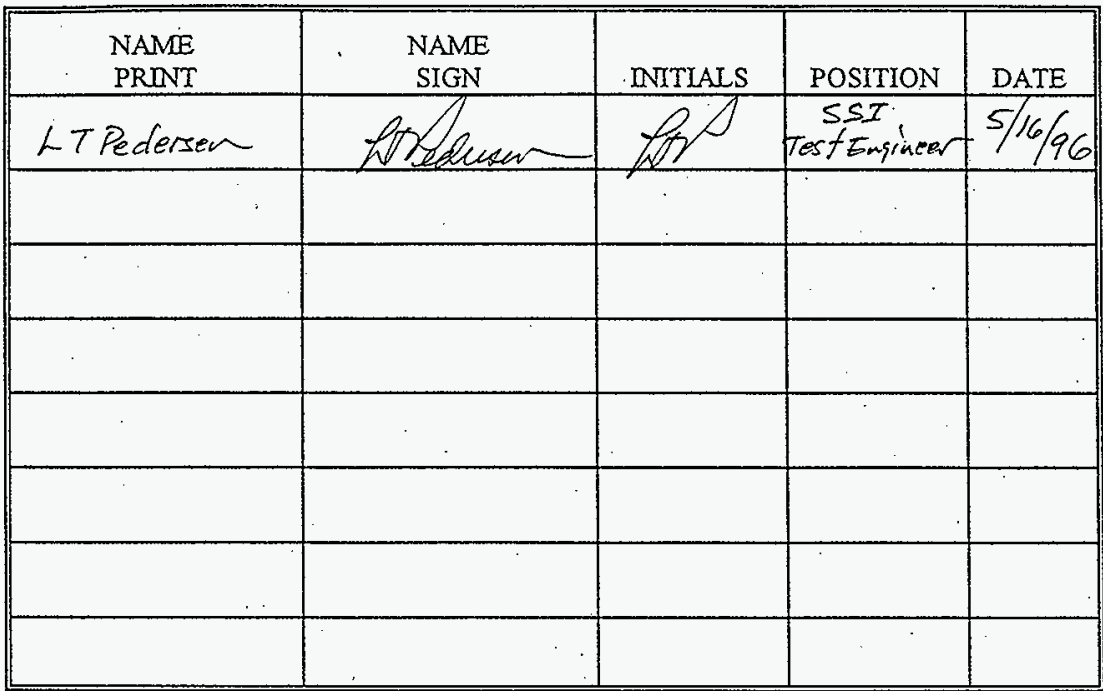

\section{Y 0.2 TEST EXECUTION RECORD}

Signature below indicates concurrence with the following:

- The objectives delineated in Section 2.0 of this procedure have been achieved.

- Ail recorded test exceptions have been resolved, the resolutions approved, and any necessary retesting completed.

- The 241-C-10 Video Camera System is ready for service.

SSI Test Engineer:

Date

Operations:

Date

QC Representative:

Date

$$
\begin{gathered}
\text { Seeterpion sheet \#2 } \\
\text { Afr } 4127198
\end{gathered}
$$

HNF-12824, Rev. 0

A2-24 
WHC-SD-W320-OTP-00S, REV. 0

11.0 EXCEPTIONS

EXCEPTION SHEET NUMBER

PROCEDURE STEP 7.8 .3

Note: Make additional copies of this page as necessary.

Description of Problem:

Wash down system washes off camera viewing windier very well in \& I minute, however, washdown system does not wash off lights effectively.

Exception Resolution:

Camera washdewn system modified in accordance

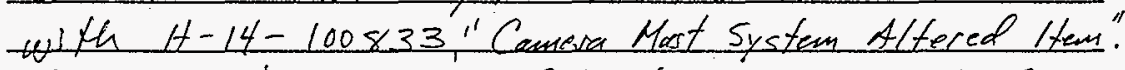
Cameron viewing window and lights yow ave washed off adequately in 60 seconds.

SSI Test Engineer: Operations: QC Representative
Date $3 / 17 / 96$ Date Date

18

$$
\text { HNF-12824, Rev. } 0
$$

A2-25 
WHC-SD-W320-OTP-005, REV. 0-A

11.0 EXCEPTIONS

EXCEPTION SHEET NUMBER 2

PROCEDURE STEP See Below.

Note: Make additional copies of this page as necessary.

Description of Problem:

Sections $8.0,9.0$, and 10.2 of this procedure lave not been completed.

Exception Resolution:

These sections have been superceeded by HNF-1823, "Acceptance Test Procedure tor the Tank 241-C-106/n' Tank Imaging System", and OT A-320-005, "Tank $241-c-106$ la -Tank Imaging system operational ( Test procedure".

Drank a line through Sections $8.0,9.0$, and 10.2 and make a reference to this exception.

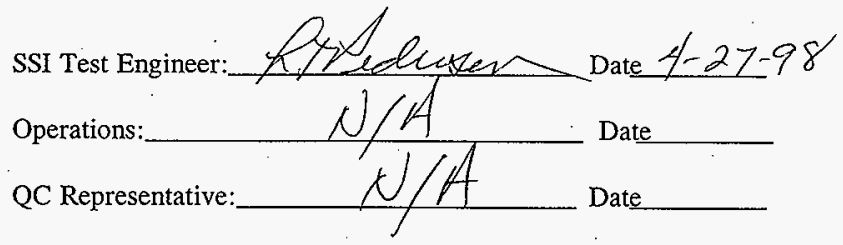

$18 a$

$$
\begin{gathered}
\text { HNF-12/824, Rev. } 0 \\
\text { A2-26 }
\end{gathered}
$$




\section{TANK 241-C-106 CAMERA ASSEMBLY}

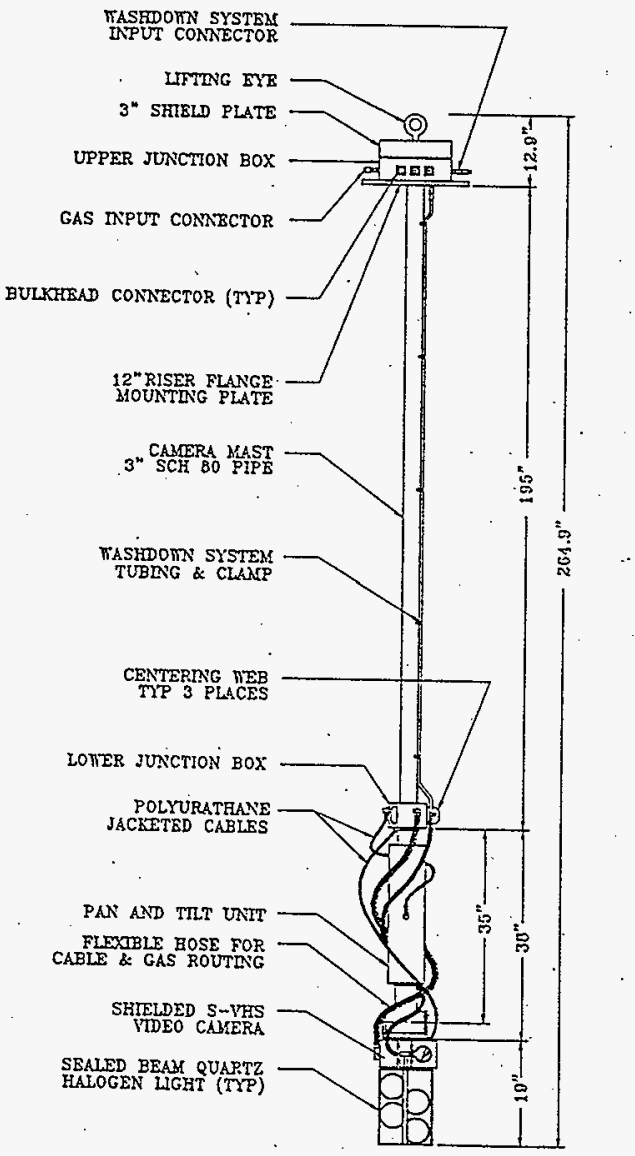

FIGURE 1 


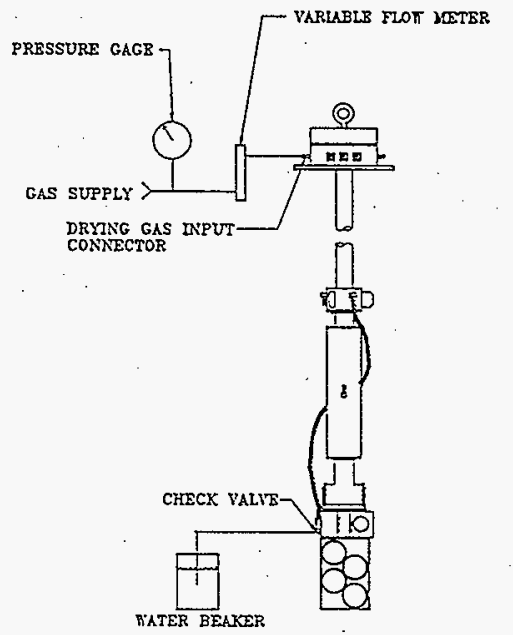

FIGURE $2 \mathrm{a}$

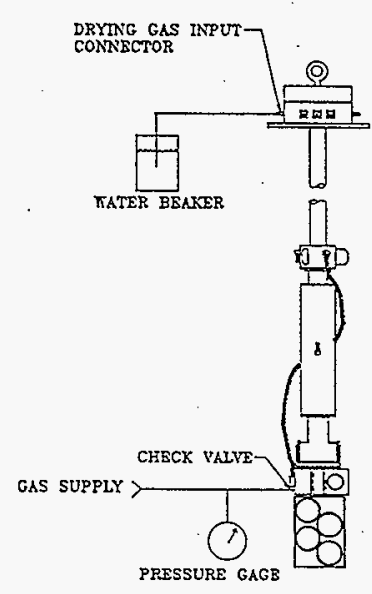

FIGURE 2b

\section{FIGURE 2}




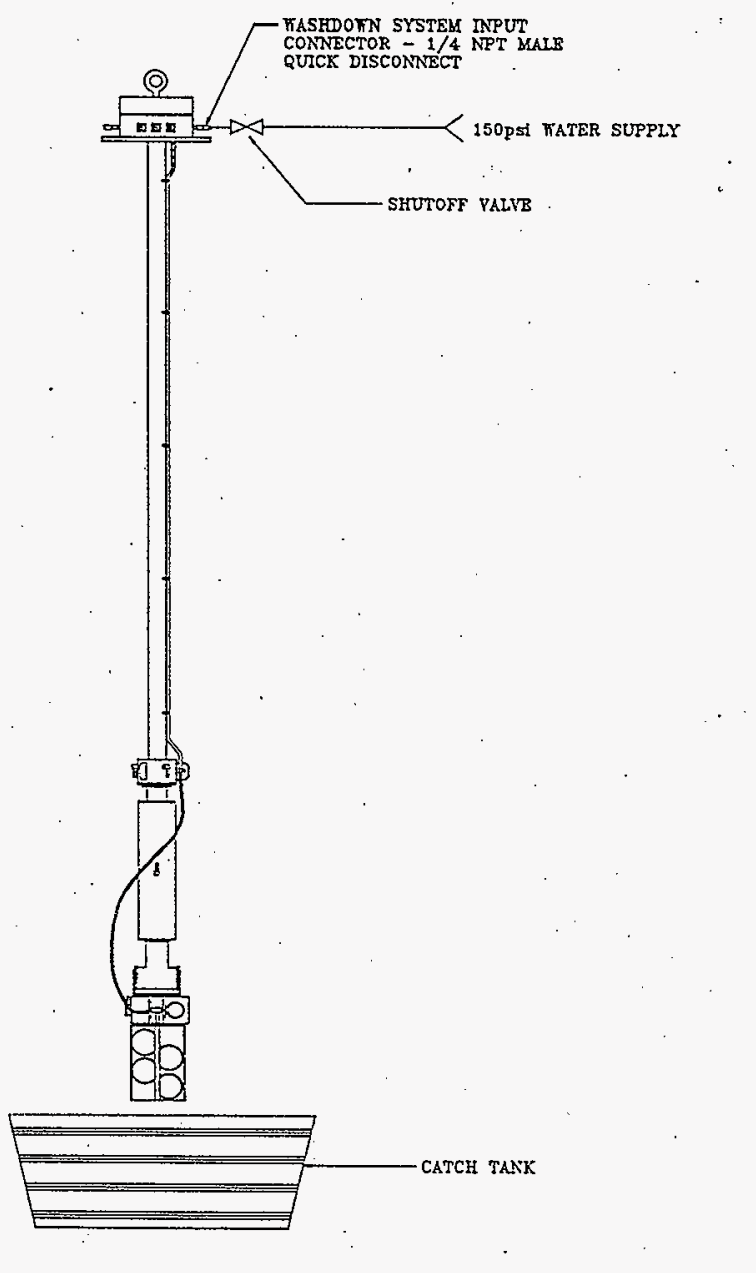

FIGURE 3 
ECN 601558 PAGE 3

WHC-SD-W320-OTP-00S REV. 0

ADDENDUM A

SHOP TEST PAN-AND-TLT MODIFICATIONS

HNF-12824, Rev. 0

A2-30 
ECN 601558 PAGE 4

WHC-SD-W320-OTP-0OS REV. 0

\subsection{ADDENDUM PURPOSE}

The W-320 camera system was modified on an emergency basis to bring it into compliance with new requirements outlined in the Flammable Gas Justification for Continued Operation (JCO). The camera system was disassembled in order to ship the camera housing and pan-and-tilt to an off-site vendor to make the required modifications. The modifications consisted of providing a flow path from the camera housing to the pan-and-tilt for instrument air. A pressure and flow sensing control system was tied into the instrument air and power feed to the camera system. These modifications were authorized by LOI \#8K800-96-027. The purpose of this addendum is to document shop testing of the modifications made to the camera system. This testing will take place in the $306 \mathrm{E}$ Building, and will be witnessed by Quality Control personnel.

\subsection{ADDENDUM TEST OBJECTIVES}

The objective of this addendum is to demonstrate and document that the modifications made to the camera system function properly when the entire camera system is reassembled. Air flow through the pan-and-tilt enclosure and newly installed relief valve will be tested. The hazardous location power controller will be tested to ensure that power is provided to the camera system only after a predetermined volume of air has flowed through the camera system enclosures. Automatic shutdown of power supplied to the camera system in the event of loss of air flow will also be demonstrated.

\subsection{ADDENDUM PROCEDURE STEPS}

\subsection{ELECTRICAL SAFETY CONTROL PANEL}

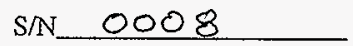

NOTE: This portion of the test is to verify that all indicators located on the front face of the Electrical Safety Control Panel (ESCP) function properly. The Time Delay Relay (TDR) unit will be set for approximately two minutes to minimize time necessary for system power up during testing.

3.1.1. POWER display located on the front face of the ESCP illuminates when the unit ON/OFF switch is moved to the ON position and power is available inside the box. Apply power to the unit and verify that the POWER light is functional. 
3.1.2 Adjust the air regulator on the supply side of the ESCP unit to approximately $35 \mathrm{psi}$ to allow for ample flow and pressure through the ESCP.

3.1.3 RESET display located on the front face of the ESCP initializes the relay logic circuitry. Press the RESET button and verify that the FLOW indicator illuminates.

3.1.4 PRESSURE displays illuminate when pressure is sensed. With the RESET button previously activated, verify that the both PRESSURE indicators illuminate.

3.1.5 PURGING display illuminates when the ESCP begins the purge cycle. After pressing the RESET button, verify that the PURGNG indicator is illuminated.

3.1.6 ENERGIZED display illuminates when the ESCP has enabled power output to the Camera/pan-and-tilt unit. After the unit has completed its two minute purge cycle, verify the ENERGIZED indicator is illuminated.

3.1.7 Verify that air flow is present at the pressure relief valve located in the top of the pan-and-tilt by placing hand over the valve.

3.1.8 Leak test (using "Snoop" or equivalent) each fitting and resolve any significant leakage by tightening the fitting. If the leakage continues, then replace the fitting. Test Engineer sign below that the system purge path is acceptable.

Test Engineer

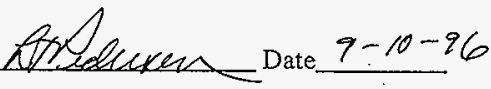

3.1.9 Witnesses sign that steps 3.1.1 through 3.1.8 are acceptable.

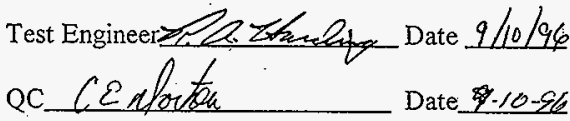

\section{LOSS OF PURGE GAS TEST}

3.2.1 Press reset button on front face of ESCP and wait for two minutes for power to the camera to come on. 
3.2.2 Manually kink the purge air supply hose cutting off flow. Verify that power to the camera system is de-energized, and that the ENERGIZED indicator is no longer illuminated.

3.2.3 Witnesses sign that steps 3.2.1 through 3.2.2 are acceptable.

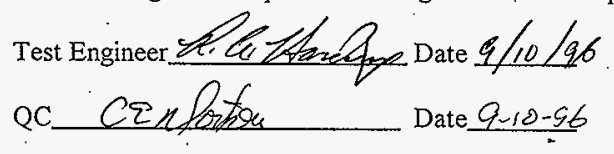

\subsection{DLFERENTIAL PRESSURE SWITCH TEST}

3.3.1 Press reset button on front face of ESCP and wait for two minutes for power to the camera to come back on.

3.3.2 Turn the air supply off. Verify that power to the camera system is deenergized, and that the ENERGIZED indicator is no longer illuminated.

3.3.3 Witnesses sign that steps 3.3.1 through 3.3.2 are acceptable.

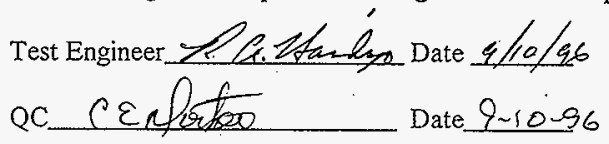

\subsection{MINIMUM ALR FLOW VERIFICATION}

NOTE: $\quad$ QC Witness sign below verifying that instrumentation listed below has been calibrated and a current calibration sticker is affixed.

- Rotameter (0-5 cfm) S/ND2-28-03-05 Cal: Due Date 10-23-96

- Pressure Gauge (0-30 psi) S/N $\leq 46-31-04-029$ Cal. Due Date $8 / 13 / 97$

QC Witness Q 10 fow Date $9-10-96$

3.4.1 Place a calibrated rotameter and pressure gauge in-line between the ESCP outlet and the camera inlet hose. 
3.4.2. Press reset button on front face of ESCP and wait for two minutes for power to the camera to come back on.

3.4.3 Decrease air flow by slowly adjusting the rotameter until power to camera is de-energized. Verify that system shutdown occurs when flow $\leq 0.9 \mathrm{cfm}$.

3.4.4 Record pressure and flow readings where camera is de-energized:

$23.6 \mathrm{psi} \quad 1.1 \mathrm{cfm}$

3.4.5 Witnesses sign that steps 3.4.1 through 3.4.4 are acceptable.

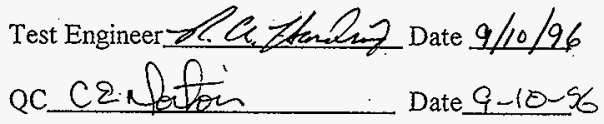

\subsection{ESCP PURGE CYCLE SETUP FOR INSTALLATION}

NOTE: - The total volume of the camera housing, pan-and-tilt, mast/junction boxes, and hoses is $2.05 \mathrm{ft}^{3}$ [ $0.09 \mathrm{ft}^{3}$ (camera housing volume) $+0.51 \mathrm{ft}^{3}$ (pan-and-tilt volume) $+0.01 \mathrm{ft}^{3}$ (hose volume) $+1.44 \mathrm{ft}^{3}$ (mast/junction boxes volume)]. Per NFPA 496 requirements, ten volumes of purge air $\left(20.5 \mathrm{ft}^{3}\right)$, must flow through the purged enclosures prior to energizing. The Time Delay Relay (TDR) located in the ESCP will be adjusted to 23 minutes $\left(20.5 \mathrm{ft} .{ }^{3} / 0.9 \mathrm{cfm}=22.8\right.$ minutes $)$ to allow for a minimum of $20.5 \mathrm{ft}^{3}{ }^{3}$. total flow prior to energizing the camera system.

\subsubsection{Adjust TDR in the ESCP to approximately 23 minutes.}

\subsubsection{Press reset button on front face of ESCP.}

3.5.3 Use stop watch (or watch with stop watch function) to verify that a minimum of 23 minutes elapse before camera system is energized. Adjust TDR and repeat as necessary.

3.5.4 Record purge cycle duration: $23: 37$

3.5.5 Witnesses sign that steps 3.5.1 through 3.5.4 are acceptable.

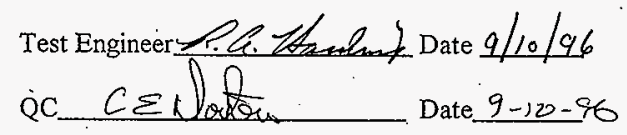


HNF-1824, Rev. 0

ATTACHMENT 3

COMPLETED COPY OF HNF-1823 


\begin{tabular}{|l|l|}
\hline $\begin{array}{l}\text { 2. To: (receiving Organization) } \\
\text { Distribution }\end{array}$ & $\begin{array}{l}\text { 3. From: (Originating Organization) } \\
\text { TWRS Equip. Engrg. }\end{array}$ \\
\hline 5. Proj./Prog./Dept./0iv.: & $\begin{array}{l}\text { 6. Design Authority/ Design Agent/Cog. } \\
\text { Engr.: } \\
\text { W-320 TWRS/TPCN D2MAI }\end{array}$ \\
\hline
\end{tabular}

8. Originator Remarks:

FOR APPROVAL AND RELEASE OF A NEH SUPPORTING DOCUMENT.

4. Related EOT NO.:
\[ \text { n/a } \]
7. Purchase Order No::
n/a

9. Equip./Component Ho.: $\mathrm{n} / \mathrm{a}$

10. System/8ldg./Facility: 241-C

12. Major Assm. Digg. Ho.: $\mathrm{H}-2-818569$ \& $\mathrm{H}-2-818690$

13. Permit/Permit Application No.: $n / a$

14. Required Response Date: 8 April 1998

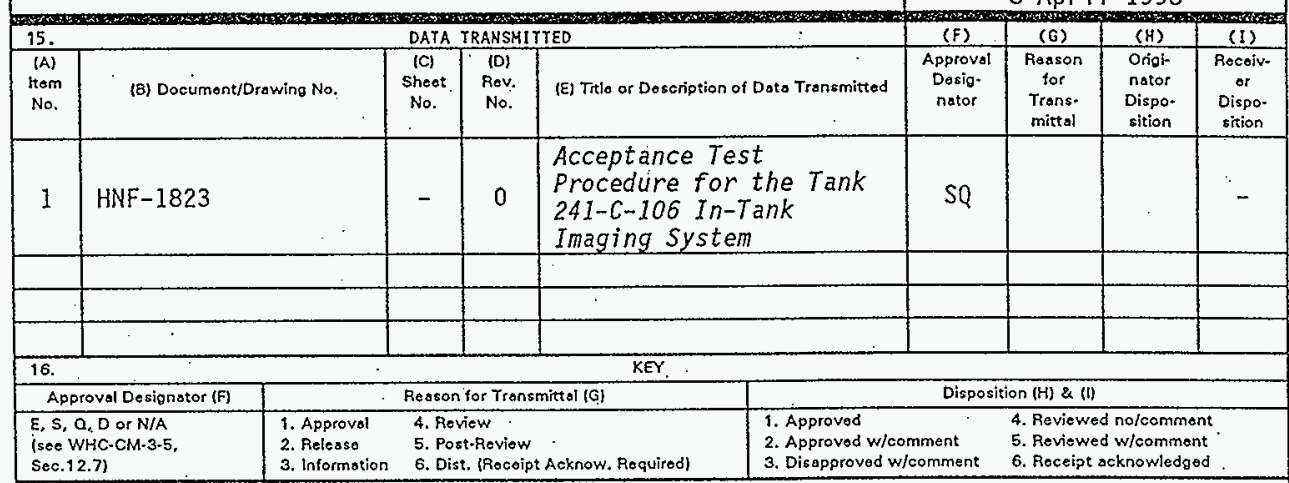

17. SIGNATUREJDISTRIBUTION

[Seo Approval Designator for requirod signatures]

\begin{tabular}{|c|c|c|c|c|c|c|c|}
\hline $\begin{array}{l}\text { (G) } \\
\text { Rea. } \\
\text { son }\end{array}$ & $\begin{array}{l}\text { (M) } \\
\text { Disp. }\end{array}$ & \multicolumn{2}{|r|}{ (K) Signaturo (L) Dg to } & $\begin{array}{l}\text { (G) } \\
\text { Res- } \\
\text { son } \\
\end{array}$ & $\begin{array}{l}(H) \\
\text { Disp. }\end{array}$ & \multicolumn{2}{|c|}{ (J) Namo (K) Signaturo (L) Dato (M) MSIN } \\
\hline 1 & $\ell$ & \multicolumn{2}{|c|}{ 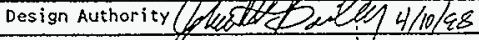 } & 1 & 1 & \multicolumn{2}{|c|}{ 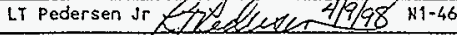 } \\
\hline & & \multicolumn{2}{|c|}{ 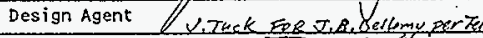 } & 1 & 1 & \multicolumn{2}{|c|}{ 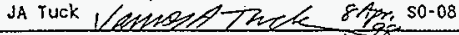 } \\
\hline 1 & 1 & \multicolumn{2}{|c|}{ Cog.Eng. J R Bellomy III Drmeeff $52-48$} & & & \\
\hline 1 & 1 & \multicolumn{2}{|c|}{ Cog. Mgr. JH Bailex buefe Solen \$2-48 } & & & & \\
\hline 1 & 1 & \multicolumn{2}{|c|}{ QA KC conrad Leethelomeses/9/sq-48 } & & & & \\
\hline 1 & 1 & \multicolumn{2}{|c|}{ Safety su Zaman Sunamau $/ / 9 / 4$ \&5-12 } & & & & \\
\hline . & & \multicolumn{2}{|c|}{ Env. } & & & & \\
\hline \multicolumn{3}{|c|}{$\begin{array}{l}\text { 8Hor, } 98 \\
\text { lampst }\end{array}$} & 19. & & & $4 / 10 / 48$ & \multirow{2}{*}{$\begin{array}{l}\text { 21. DOE APPROVAL (if required) } \\
\text { Ctrl. Ho. } \\
\text { (2) Approved } \\
\text { [\} Approyed } \mathrm{H} / \text { coments } \\
\text { [1 Disapproved } \mathrm{w} / \text { comments }\end{array}$} \\
\hline \multicolumn{3}{|c|}{$\begin{array}{l}\text { Signature of EOT } \\
\text { Originator }\end{array}$} & $\begin{array}{l}\text { Authorized Representative Daie } \\
\text { for Recoiving Orgenization }\end{array}$ & & ityd & Dote & \\
\hline
\end{tabular}




\section{Acceptance Test Procedure for the Tank 241-C-106 In-Tank Imaging System}

James A. Tuck

for Numatec Hanford Co./Lockheed Martin Hanford Co., Richland, WA 99352 U.S. Department of Energy Contract DE-AC09-96RL13200

EDT: 624388

Org Code: 64114

B\&R Code: EW3130010
UC: 506

Charge Code: . D2MA1

Total Pages: 14

Key Hords: CCTV, camera, sluicing, waste retrieval, Project $W-320$

Abstract: This document comprises an acceptance test procedure of an In-Tank Imaging (Camera) System to support siuicing and waste retrieval from Tank C-106 under Project $\mathrm{H}-320$ :

TRADEMARK DISCLAIMER. Reference herein to any specific commercial product, process, or service by trade name, trademark, manufacturer, or otherwise, does not necessarily constitute or imply its endorsement, recommendation, or favoring by the United States Government or any agency thereof or its contractors or subcontractors.

Printed in the United States of America. To obtain copies of this document, contact: WHC/BCS Document Control Services, P.O. Box 1970, MaiTstop H6-08, Richland WA 99352, Phone (509) 372-2420;

Fax (509) 376-4989.

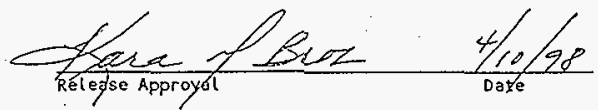

Approved for Public Rélease

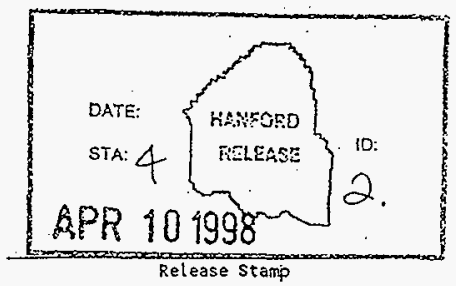

HNF-12824, Rev. 0 
1.0 PURPOSE $\ldots \ldots \ldots \ldots \ldots \ldots \ldots$

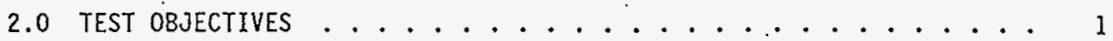

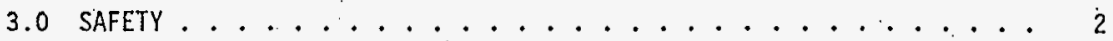

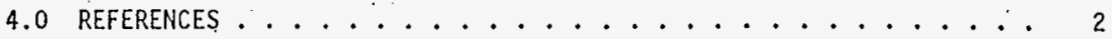

5.0 RESPONSIBILITIES . . . . . . . . 2

5.1 MAINTENANCE AND SURVEILIANCE ENGINEERING $\therefore \therefore 2$

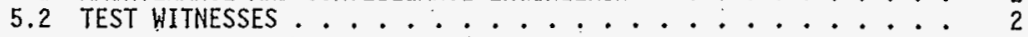

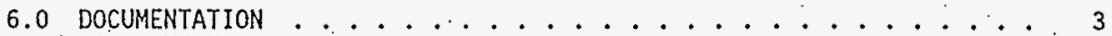

6.1 TEST RECORD ........................ 3

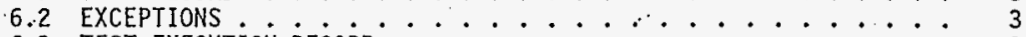

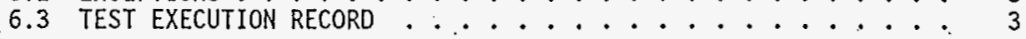

7.0 ACCEPTANCE TEST

7.1 ACCEPTANCE TEST CAMERA ELECTRICAL, COMPRESSED AIR, WATER, AND
HAZARDOUS LOCATION POHER CONTROLLER

7.2 ACCEPTANCE TEST CAMERA SYSTEM CONTROLS - MASTER CONTROL

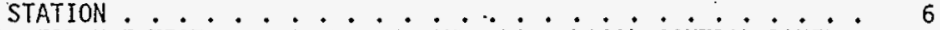

7.3 ACCEPTANCE TEST CAMERA SYSTEM CONTROLS - LOCAL CONTROL PANEL : 7

7.4 ACCEPTANCE TEST HLPC SHUTDOWN INTERLOCK $\ldots \ldots . . . \ldots$

7.5 ACCEPTANCE TEST INSTALLED CAMERA SYSTEM ......... 8

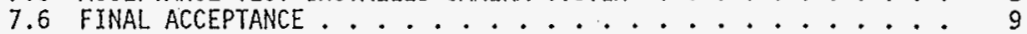

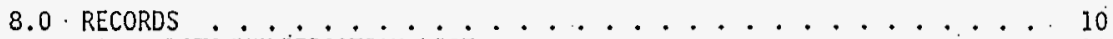

8.1 DATA/VERIFICATION LIST . . . . . . . . . . . 10

8.2 TEST EXECUTION RECORD . . . . . . . . . 10

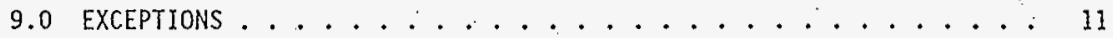

FIGURE: TANK 241-C-106 CAMERA ASSEMBLY, PHYSICAL ARRANGEMENT . . . . 12 
HNF-1823, REV. 0

ACCEPTANCE TEST PROCEDURE FOR THE TANK 241-C-106

IN-TANK IMAGING SYSTEM

\subsection{PURPOSE}

This acceptance test procedure (ATP) will document the satisfactory operation of the 241-C-106 Video Imaging System. Included in the video imaging system. are the camera assembly, master control station, local control panel, and system interconnection cables. The camera assembly consists of the camera mast, pan-and-tilt unit, camera, lights, washdown system, and purge system. The camera assembly will be installed in Tank 241-C-106 to monitor activities during the $W-320$ Project. See the attached Figure for a diagram of the camera assembly.

The In-Tank Imaging System is being tested in three separate phases as identified below:

- A shop test of the camera assembly. Was performed in the $306 \mathrm{E}$ Building as a prerequisite to acceptance and operational testing. The shop test was performed in accordance with Section 7.0 and Addendum A of WHC-SD-W3200TP-005, Tank 241-C-106 In-Tank Imaging System ATP/OTP. A11 components of the camera system, including the camera assembly, controllers; lights, monitor, video tape recorder, cabies, and character generator were assembled and tested. The camera assembly was lifted with a $306 \mathrm{E}$. Building overhead crane by qualified facility personnel, and testing was performed while the assembly was suspended from the crane.

- This Acceptance Test Procedure will be performed in accordance with this document at the 200 East Area at the 241-C Tank Farm, following installation of the master control. station components, cables, and local interface panels. The camera assembly will be. lifted by a mobile crane in accordance with an approved procedure. The acceptance test will be performed while the camera assembly is suspended from the crane prior to installation into tank 241-C-106. The acceptance test will also include a brief, post-installation check of camera function to verify proper installation.

- An operational test will be performed following installation of the camera assembly into tank 241-C-106, in accordance with tank farm procedure OTP-320-005.

\subsection{TEST OBJECTIVES}

The objective of this procedure is to demonstrate and document acceptance of the 241-C-106 camera system,- just prior to installing the camera in the tank. The camera focus, zoom, and iris remote controls will be functionally tested. The pan-and-tilt unit will be tested for required ranges of motion, the camera lights and washdown system will be functionally tested. Acceptance testing wili also verify that connections are properly made and the system is ready for operational testing, following camera installation.

The master control station equipment, including the monitor, video cassette recorder (VCR), and camera control unit will be set up and tested. The Hazardous Location Power Controller (HLPC) will be tested to ensure that the required purge cycle is completed before the power to the camera assembly is 
HNF-1823, REV. 0

energized. The HLPC shutdown interlock wil? also be tested to ensure that power to the camera assembly is de-energized when purge gas (instrument air) flow is interrupted.

\subsection{SAFETY}

Safety is of primary importance throughout all phases of this procedure. 0nly the test director, cognizant test engineer, or their approved delegate shall operate the camera equipment. A pre-job safety briefing shall be conducted with all involved test personnel, and documented on the Job Hazard Analysis sign-off sheet.

Acceptance testing will be performed at 241-C. Tank Farm in the 200 East Area, immediately prior to camera installation. The camera installation package (JCS $\frac{n}{\pi} 2 E-97-2230$ ) will designate safety requirements for the acceptance test.

\subsection{REFERENCES}

H-2-818448, Sh. 4

H-2-818559, Sh. 3

$\mathrm{H}-2-818561$, Sh. 5

$\mathrm{H}-2-818590$, Sh. 1

$\mathrm{H}-2-818690$, Sh. 1

JCS. \#2E-97-2230

HHC-S-0439

WHC-SD-W320-TP-001
Structural 241-C-06A Pump Pit Mod Cover Block Sections and Details

Project $\mathrm{H}-320$ P\&ID Tank 241-C-106

Project $W-320$ P\&ID TK 241-C-106 HVAC

Operator Control Station. Plan

C-Farm In-Tank Imaging (CCTV)

Installation of C-106 CCTV (Job Control System Work Package)

Specification for Procurement of Color Video Imaging System for Waste Tank 241-C-106

Project H-320, Tank 24I-C-106 Waste Retrieval Sluicing System, Testing Plan"

\subsection{RESPONSIBILITIES}

\subsection{MAINTENANCE AND SURVEILLANCE ENGINEERING}

A Maintenance and Surveillance Engineering (MSE) Test Engineer shall be responsible for the performance and documentation of the test procedure.

\subsection{TEST WITNESSES}

Tank Farm Operations and Quality Control will provide a representative to witness the satisfactory completion and approval of pertinent steps identified in this procedure. Witnesses are responsible for verifying that organizational requirements are met throughout the testing and documentation sequences of the procedure. 


\subsection{DOCUMENTATION}

\subsection{TEST RECORD}

A1l personnel involved in the performance of this test, including the MSE Test Engineer, shal1 fill out a line in Section 8.1, "Data/Verification List".

Test results shall be recorded by the MSE Test Engineer. Test steps which require the recording of specific data shall be completed by the MSE Test Engineer. The signature $(s)$ of the person(s) accepting the test sections will be entered in the appropriate place following the test section indicating compliance with the stated requirements or the successful completion of the given test steps. Unacceptable conditions or readings are to be recorded in Section 9.0, "Exceptions".

The MSE Test Engineer wi7l maintain a chronological test log documenting when various phases of the test are conducted and any pertinent information not recorded in the test procedure.

\subsection{EXCEPTIONS}

Exceptions by step number, and other notes, are to be recorded in Section 9.0. This section must be dispositioned (including the generation of any required ECNS) and signed off prior to final test results acceptance. If no exceptions are encountered, this may be so noted and the section closed out by the MSE Test Engineer.

During the performance of this test, errors in text may be encountered which require correction or adjustment to complete the test. The correction is to be noted in the ATP and Tisted as an exception in Section 9.0.

\subsection{TEST EXECUTION RECORD}

Final acceptance of the test results shall be indicated by signatures listed under Section 8.2; Test Execution Record.

\subsection{ACCEPTANCE TEST}

\section{NOTE:}

During the acceptance test the MSE Test Engineer will verify each camera control is satisfactory and will initial steps to signify completion. The MSE Test Engineer and witnesses will also sign off in the spaces provided at the end of each section. The sequence of steps in the acceptance test section may be altered at the discretion of the MSE Test Engineer.

7.I ACCEPTANCE TEST CAMERA ELECTRICAL, COMPRESSED AIR, WATER, AND HAZARDOUS LOCATION POHER CONTROLLER

7.1.1 Connect the three (3) 50-ft camera testing cables (R09810, R8504 and $R 12364$ ) to the appropriate bulkhead connectors in the camera upper junction box and to the appropriate connectors located on the underside of the FCU. local interface unit [NOTE: These three 
cables are for temporary control of the camera, pan-and-tilt, and camera lights. As a safety precaution, each of these cables have different connectors and cannot be accidentally interchanged].

7.1.2. Connect the 450-ft $R 4404$ camera contro1.cable to the appropriate connector on the underside of the FCU local interface unit and to the connector on the back of the camera control unit in CP-02 [NOTE: To prevent improper connection, this cable has connectors which are different from all other system connectors].

7.1.3 Connect the 10-ft R12364 local control cable to the connector on the front face of the local control unit inside the local control panel enclosure and to the connector on the underside of the FCU Tocal interface unit [NOTE: To prevent improper connection, this cable has connectors which are different from all other system connectors].

7.1.4 Connect the 5-ft R7504 washdown system cable to the connector on the washdown solenoid enclosure and to the appropriate connector on the FCU Tocal interface unit [NOTE: To prevent improper connection, this cable has connectors which are different from all other system connectors].

7.1.5 Connect the power cable and the differential pressure switch cable to the appropriate connectors on the underside of the FCU local interface unit and to the connectors on the underside of the Hazardous Location Power Controller (HLPC) enclosure.

7.1.6 Attach the 50-ft test hose to the camera upper junction box washdown system quick disconnect coupling and to the output of the camera washdown solenoid enclosure. Open water valves HV-136108 (in Process Building) and HV-13657 (near solenoid enclosure). open the ball valve located inside the washdown solenoid enclosure.

7.1.7 Attach the 50-ft test hose to the camera upper junction box purge gas system pneumatic quick disconnect coupling and to the air outlet connector on the HLPC. Open instrument air valve HV-13676 (near HLPC).

7.1.8 Verify air pressure is in the range of 30 to 40 psi on the HLPC air pressure gage (on front inside panel of the HLPC enclosure).

7.1.9 Verify that purge gas (instrument air) is flowing out of the check valve in the top of the pan-and-tilt housing.

7.1.10 Close process building panelboard breaker for IN-TANX CCTV FCU-1361 C106-PPI/\#6 (ON position).

7.1.11 CTose process building panelboard breaker for GFCI RCPT AT FCU-1361 RACK C106-PP1/\$9 (ON position).

7.1.12 Using the VOM, measure and verify the voltage at the FCU receptacle is in the range of 114 to 126 VAC. 
HNF-1823, REV. 0

7.1.13 Verify that the GFCI feature of the FCU receptacle functions properiy via the test and reset buttons.

7.1.14 Close M0-211 panelboard breaker for CP-02 IN TANK IMAGING RCPTS PNL-M0211/\#3 (ON position).

7.1.15 Using the VOM, measure and verify the voltage at the master control station CP-02 surge suppressor receptacle is in the range of 114 to 126 VAC.

7.1.16 Connect power cords from CP-02 master control station monitor, VCR, and camera control unit to $\mathrm{CP}-02$ surge suppressor receptacie.

7.1.17 Connect an S-VHS video cable from the CP-02 master control station camera control unit "S-VHS OUT" terminal to the Video Tape Recorder "S-VIDEO INPUT" terminal. Connect an S-VHS video cable from the Video Tape Recorder "S-VIDEO OUT" terminal to the monitor "Y/C IN" terminal.

7.1.18 Connect the CP-02 master control station keyboard to the camera control unit keyboard terminal.

7.1.19 Start camera purge timing sequence by pressing "RESET" button on front inside pane] of HLPC.

Verify. that camera purge timing sequence lasts a minimum of 23 minutes.

7.1 .21

Verify that red "ENERGIZED" Tamp on front inside panel of HLPC comes on, indicating that power is now available to the camera system.

7.1.22 Using the VOM, measure and verify the line side voltage at the FCU local interface unit disconnect switch, located inside the local interface unit enclosure, is in the range of 114 to 126 VAC.

7.1.23 Verify, that camera washdown system operates from local control panel.

7.1.24 Verify that camera washdown system operates from master contro] station.

7.1.25 Record serial number of HLPC:

0008

7.1.26 Steps 7.1.1 through 7.1.25 are/complete and acceptable.

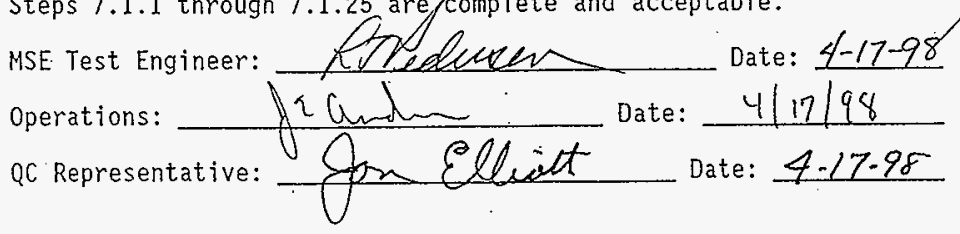




\subsection{ACCEPTANCE TEST CAMERA SYSTEM CONTROLS - MASTER CONTROL STATION}

NOTE:

The Master Control Station is located in M0-211 (Operator Control Station).

7.2.1 Energize the monitor, video recorder, character generator, and camera control unit. Verify these components have power and are operational.

7.2.2 Verify that the lighting system is operational and variable controllers are functioning.

7.2.3 Using pan and tilt controls, pan in the clockwise direction until the stop is reached. Verify that the pan electronic brake holds.

7.2.4 Pan in the opposite direction until the stop is reached. Verify that the pan electronic brake holds.

7.2.5 Tilt the camera to the vertical down position. Verify that the electronic brake holds.

7.2.6 Tilt camera upward until the stop is reached. Verify that the electronic brake holds.

7.2.7 Manipulate the camera zoom control to wide angle. Verify zoom moves towards wide when operated towards "WIDE".

7.2.8 Manipulate the camera zoom control to telephoto. Verify zoom moves towards telephoto when operated towards "TELE".

7.2.9 Manipulate the camera iris control to open. Verify that the iris opens when operated towards "OPEN".

7.2.10 Manipulate the camera iris control to close. Verify that the iris closes when operated towards "CLOSE".

7.2.11 Manipulate the camera focus control to far. Verify that the focus adjusts to far when operated towards "FAR".

7.2.12 Manipulate the focus control to near. Verify that the focus adjusts to near when operated towards "NEAR".

7.2.13 Verify that there is a color image on the camera system monitor, and that the image is free of defects such as ghosts, lag, distortion, hum, or smearing.

7.2.14 Steps 7.2.1 through 7.2.13 are complete

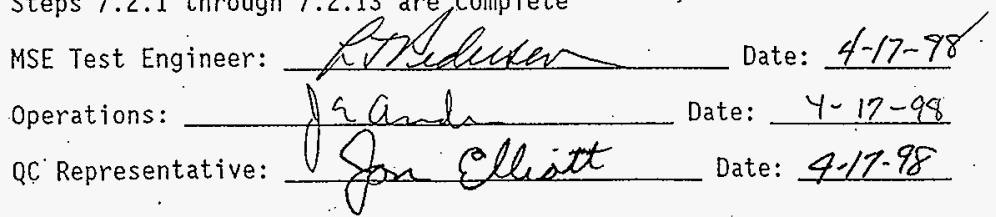


HNF-1823, REV. 0

7.3 ACCEPTANCE TEST CAMERA SYSTEM CONTROLS - LOCAL CONTROL PANEL

NOTE:

The Local Control Panel is Tocated adjacent to Tank 241-C-106, mounted to the FCU.

7.3.1 . Energize all components. Verify each component for power and operability.

7.3.2 Attach an auxiliary monitor to the video output of the local control panei. Verify that monitor is operational.

7.3.3 Verify that the lighting system is operational and variable controliers are functioning.

7.3.4 Using pan and tilt controls, pan in the clockwise direction untit the stop is reached. Verify that the pan electronic brake holds.

7.3.5. Pan in the opposite direction until the stop is reached. Verify that the pan electronic brake holds.

7.3.6 Tilt the camera to the vertical down position. Verify that the electronic brake holds.

7.3.7 Tilt camera upward until the stop is reached. Verify that the electronic brake holds.

7.3.8 Manipulate the camera zoom control to wide angle. Verify zoom moves towards wide when operated towards "WIDE".

7.3.9 Manipuiate the camera zoom control to telephoto. Verify zoom moves towards telephoto when operated towards "TELE".

7.3.10 Manipulate the camera iris control to open. Verify that the iris opens when operated towards "OPEN".

7.3.11 Manipulate the camera iris control to close. Verify that the iris closes when operated towards "CLOSE".

7.3.12 Manipulate the camera focus control to far. Verify that the focus adjusts to far when operated towards "FAR".

7.3.13 Maniputate the focus control to near. Verify that the focus adjusts to near when operated towards "NEAR".

7.3.14 Verify that there is a color image on the camera system monitor, and that the image is free of defects such as ghosts, lag, distortion, hum, or smearing. 
7.3.15 Steps 7.3.1 through 7.3.14 are complete.

MSE Test Engineer: APRedecken Date: $4-17-28$

operations: fochdo Date: $4-17-98$

QC Representative:

Date: $4 \cdot 17 \cdot 58$

\subsection{ACCEPTANCE TEST HLPC SHUTDOWN INTERLOCK}

7.4.1 Close the instrument air valve HV-13676 (near HLPC), shutting off the air flow to the HLPC.

7.4.2 Verify that power to the camera assembiy is de-energized.

7.4.3 Steps 7.4.1 and 7.4.2 are complete and acceptable.

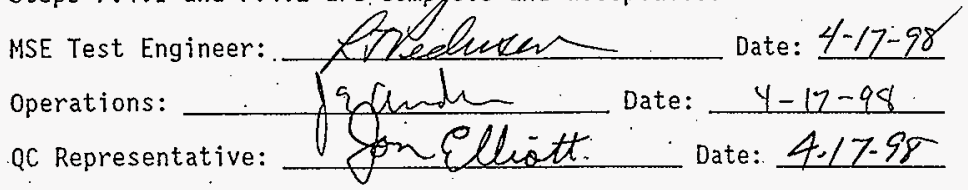

\subsection{ACCEPTANCE TEST INSTALLED CAMERA SYSTEM}

7.5.I Verify camera system is installed per referenced drawings and work package $\# 2 E-97-2230$, including the following permanent connections from the installed camera system to the Local Control Panel and M0-21l Operator Control Station:

- WIRE RUNS $\#-099, \#-100$, AND $\#-101$ ("VENDOR-FURNISHED CABLES", REF. H-2-818690)

- FLEX HOSES FOR INSTRUMENT AIR AND WATER (PART NOS. $15 \& 16$ ON H-2-818569; ALSO REF. H-2-818690).

7.5.2 Repeat steps from above ATP test sections, as necessary, at the direction of the MSE Test Engineer, to verify function of installed camera system.

7.5.3 Steps 7.5.1 and 7.5.2 are complete and acceptable. MSE Test Engineer: A Redewer Date: 4-22-98 
HNF-1823, REV. 0

7.6 FINAL ACCEPTANCE

Acceptance testing per this procedure is completed satisfactorily and the 241-C-106 Video Camera system is ready for operational testing.

MSE Test Engineer:

Date: $4-22-98$

operations:

Date: $y-22-98$

QC Representative:

Gi and Elliot s

Date: $4.22-98$

9

HNF-12824, Rev. 0

A. $3-13$ 


$$
\begin{gathered}
\text { HNF-1823, REV. } 0 \\
8.0 \text { RECORDS }
\end{gathered}
$$

8.1 DATA/VERIFICATION LIST

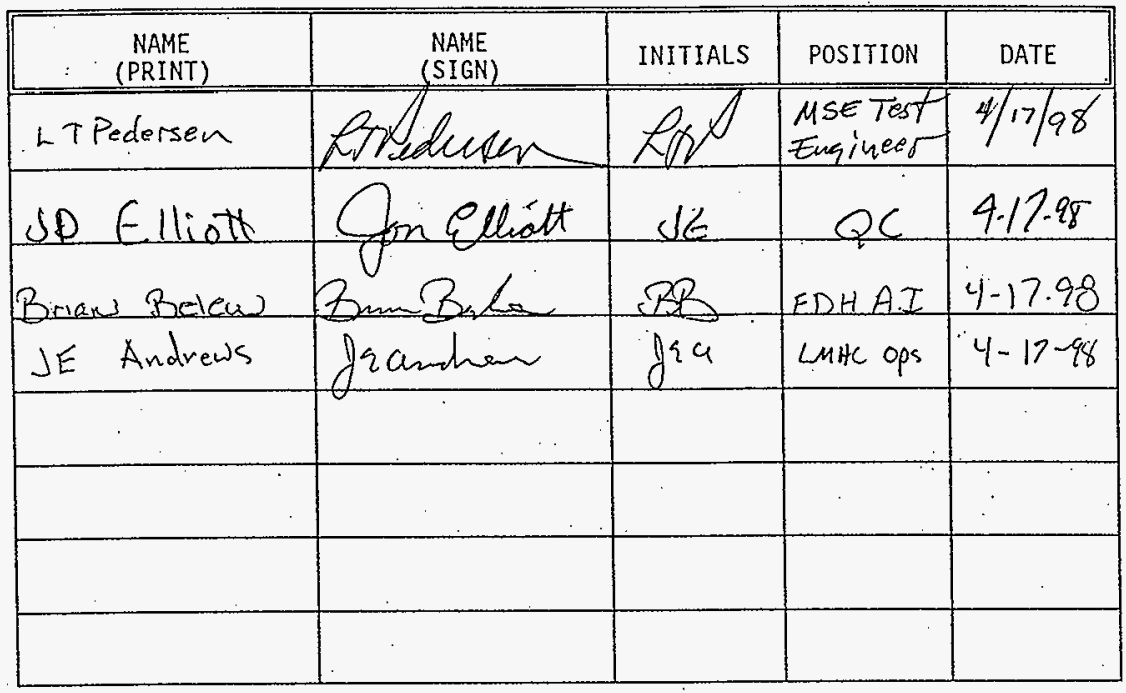

8.2 TEST EXECUTION RECORD

Signature below indicates concurrence with the following:

- The objectives delineated in Section 2.0 of this procedure have been achieved.

- All recorded test exceptions have been resolved, the resolutions approved, and any necessary retesting completed.

- The 241-C-106 Video Camera System is ready for operational testing.

MSE Test Engineer: operations: $f$ \& and QC Representative: FD AI.

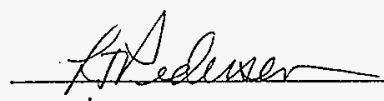

Son Elliott Date: $4-22-98$ Date: $4-22-98$ Date: 4.22 .98 4.22 .98

10 HNF-12/824, Rev. 0 A3-14 
HNF-1823, REV. 0

9.0 EXCEPTIONS

EXCEPTION SHEET NUMBER: 1

PROCEDURE STEP: 7.1 .20

NOTE: Make additional copies of this page as necessary.

Description of Problem:

Purge cycle timing is set to 22 min $15 \mathrm{sec}$ rather than min. of 23 minutes.

Exception Resolution:

the mini purge cycle timing of 23 minutes is based on camera system volume and purge gas flow res calculated in whte-50-W320-070-005, Adidondun A,

section 3.5. That calculation is based on a min. fen pate of $0.9 \mathrm{sctm}$. In step 3.4 .4 of $430-50-1320-0+0-005$, Addendum $A$ the actual min. flow rate for operation of taPe $5 / \mathrm{m} 0008$ is $1.1 \mathrm{scFm}$. thus, the ten volume purge air exchange required by NFPA-496 is actually achieved after a purge cycle af 18.6 minutes $\left(20.5 \mathrm{ft}^{3} / 1 \mathrm{~cm}=\right.$ $18.6 \mathrm{~min}$.)

MSE Test Engineer: Date: $4-17-98$

Operations:

q and Date: $y-17-98$

QC Representative:

Elliott

Date: $4,17.98$

11

$$
\begin{gathered}
\text { HNF-1/2824, Rev. } 0 \\
\text { A3-15 }
\end{gathered}
$$


HNF-1823, REV̈. 0

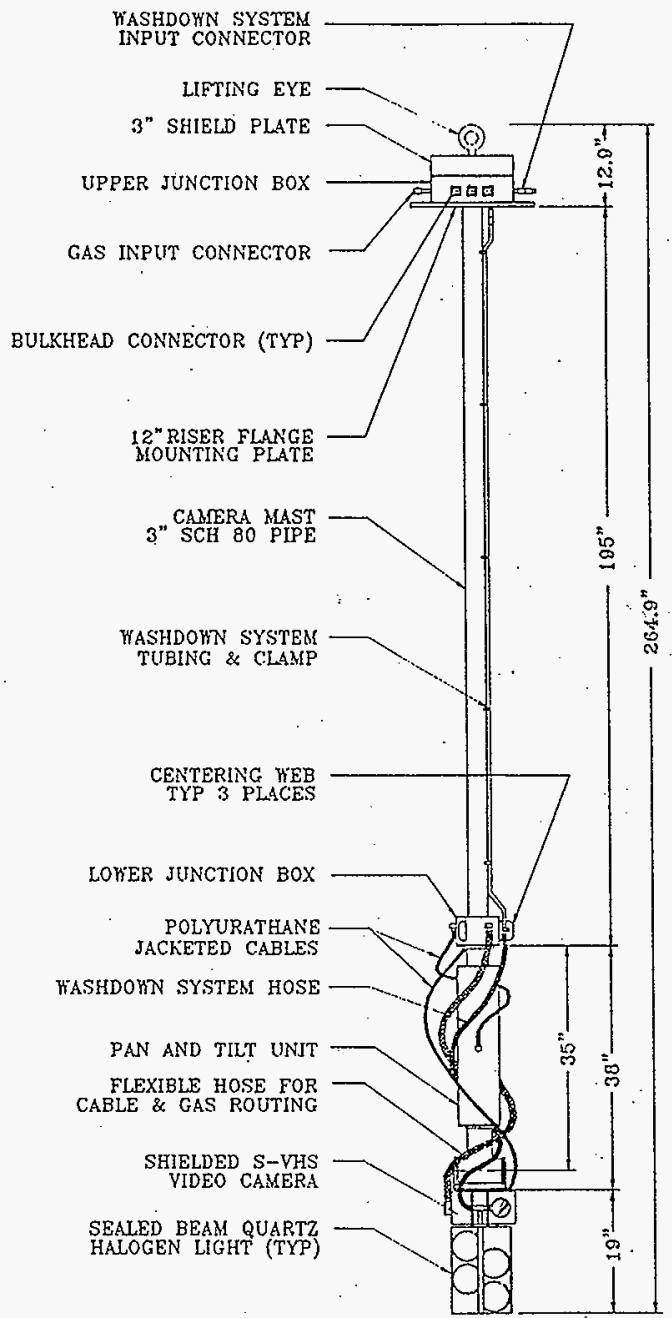

FIGURE: TANK 241-C-106 CAMERA ASSEMBLY, PHYSICAL ARRANGEMENT 